\title{
Foraminiferal distribution and palaeoecological interpretation of the Eocene-Miocene carbonates at Al Jabal al Akhdar (northeast Libya)
}

\author{
ESAM O. ABDULSAMAD \& ROBERTO BARBIERI
}

Dipartimento di Scienze della Terra e Geologico-Ambientali, Universitá di Bologna, Via Zamboni, 67, 40126 Bologna, Italy

\begin{abstract}
In the coastal area of northeastern Cyrenaica (Libya), the excellent exposures of Cenozoic limestone sequences of $\mathrm{Al} \mathrm{Jabal} \mathrm{al} \mathrm{Akhdar} \mathrm{average} \mathrm{around} 1000 \mathrm{~m}$ in thickness and allow detailed stratigraphic investigations to be undertaken. This study of the biostratigraphy and depositional environments has been augmented by an analysis of the microfacies and of matrix-free foraminiferal assemblages. The biotic contents of the microfacies provide a good tool for correlation with the Letter classification developed from the Indo-Pacific region. The palaeoecological significance of the biota has been evaluated by comparison with the ecological requirements of their present day counterparts. Limitations for the palaeoecological interpretations are mainly due to the inadequate relationships with existing ecological data sets and to some local bias in fossil recovery because of some unfavourable lithologies. In the investigated Eocene to Miocene shallow marine carbonate succession nine different microfacies and sub-microfacies were distinguished through depositional texture and biotic components. Wilson's standard carbonate facies belts, integrated with present day foraminiferal distribution models, have been used for reference in microfacies analysis and description. Most of the microfossils present are foraminifera and a total of 150 taxa, including larger, small and planktonic foraminifera, have been recognized and their stratigraphic and palaeaeocological distribution reported. Physiographically, the rock sequences investigated are referred to a shelf-carbonate platform complex, in which the depositional environments range from open shelf to restricted platform conditions. The nature and distribution of the foraminiferal assemblages and related biota, in association with sedimentological evidence, indicate a generalized shallowing upward trend in which several bathymetric oscillations, especially in the Oligocene, are reported. These reflect the interplay between local tectonics and large-scale eustatic changes. $J$. Micropalaeontol. 18(1): 45-65, June 1999.
\end{abstract}

\section{INTRODUCTION}

Al Jabal al Akhdar (Green Mountain) lies in northern Cyrenaica, northeastern Libya, and has excellent surface exposures of Meso-Cenozoic sedimentary sequences. The Cenozoic interval consists of about $1000 \mathrm{~m}$ thick deposits that range in age from Palaeocene to Late Miocene. The study area is broadly located between 32 and $33^{\circ} \mathrm{N}$ latitude and 21 to $23^{\circ} \mathrm{E}$ longitude (Fig. 1). Two successions were investigated for their microfacies and foraminiferal content in the Middle EoceneMiddle Miocene interval. The first succession was measured from a new roadcut exposure along the Cyrene-Apollonia highway (CA section), while the second is from well A1-36, an exploration borehole drilled in the early 1960s by the Arabian Gulf Oil Company (Figs. 1 and 2).

The purpose of this study is to provide the first comprehensive account of the micropalaeontology of the middle Cenozoic in the central Al Jabal al Akhdar by using a reference section (CA section) and a supplementary section, the latter to include a significantly thick and fossiliferous Miocene interval which is absent in the CA section. Depending on the lithology, the biotic content changes remarkably and, consequently, its resolution potential. Although no formally established biozones have been generally used because of the rarity of species useful for biozone recognition, a biostratigraphic framework has been developed using the many age-diagnostic taxa recovered. Information derived from the microfacies and the matrix-free foraminiferal assemblages, and analogy with present day phylogeneticallyrelated taxa, have been used for the palaeoenvironmental analysis. In general, each of the four main lithostratigraphic

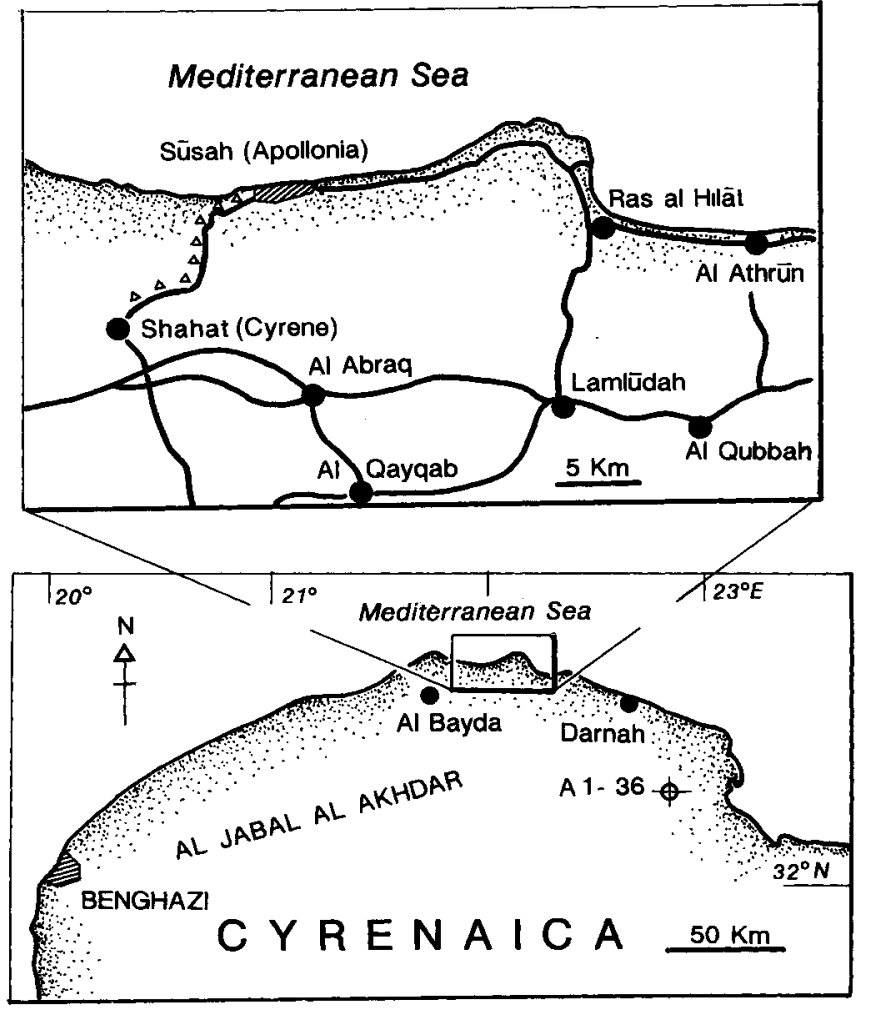

Fig. 1. Map of northern Cyrenaica showing location of the CyreneApollonia (CA) section and well Al-36. 


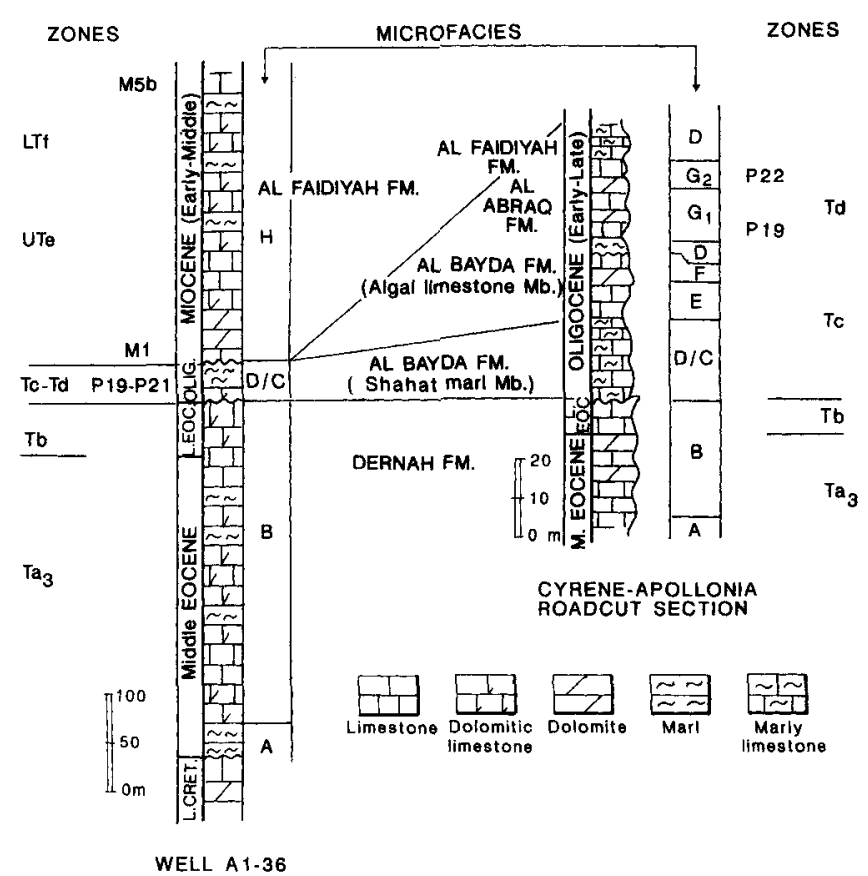

Fig. 2. Stratigraphic logs and correlation of the Cyrene-Apollonia (CA) section and well A1-36. T Zones refer to the Letter zonation of Adams $(1970,1984)$; P-M zones refer to the planktonic foraminiferal zonation of Berggren \& Miller (1988) and Berggren et al. (1995).

units making up the studied succession represents a shallowingup sequence. These developed in various parts of a shelfcarbonate platform complex whose biotic content is only occasionally eliminated by dolomitization of diagenetic origin.

\section{GEOLOGICAL SETTING AND STRATIGRAPHY}

Al Jabal al Akhdar has been interpreted as an anticlinorium by Christie (1955), who described the geological structure of the region. This uplift can be broadly traced from near Benghazi to $200 \mathrm{~km}$ eastwards and, on the flanks of this large structure (north-south width $75 \mathrm{~km}$ ), Cretaceous, Palaeocene, Eocene, Oligocene and Miocene limestones and marls are exposed. The total maximum thickness of the exposed sedimentary rocks exceeds $2000 \mathrm{~m}$. Because the core of the structure has been uplifted since Cretaceous times, the Cenozoic successions are generally thick on the flanks of the anticlinorium (e.g. in well A1-36), whereas towards the crest they thin and are interrupted by unconformities (e.g. in the CA section). The anticlinorium is intersected, and in part bounded, by faults, most of which show a displacement upwards on that side of the fault closest to the crest of the structure. However, most of the upwards movement of the core has been accomplished by folding or flexing the rocks. The Cretaceous rocks are the most strongly folded and faulted, whereas the Eocene, in the coastal region resting unconformably on the Cretaceous, and the Oligocene and Miocene rocks are less strongly folded and rarely dip at angles greater than $10^{\circ}$ (Eocene) to $3^{\circ}$ (Oligo-Miocene) (Christie, 1955). In the sections investigated, four formations ranging in age from the Middle Eocene to the Middle Miocene have been recognized. These are the Dernah, Al Bayda, Al Abraq and Al Faidiyah
Formations. Several workers, including Barr \& Weegar (1972), Klen (1974), Röhlic (1974), Zert (1974), Banerjee (1980), and El Hawat \& Shelmani (1993), have described these units, both at outcrop and in the subsurface.

The Middle to Late Eocene Dernah Formation (Gregory, 1911) has its type area near the town of Dernah, on the northern Cyrenaica coastal plain. In the area of this study, the Dernah Formation consists of hard and massive beds of fine- to coarsegrained, whitish to yellowish limestone, with intercalations of dolomitic limestone. The thickness is only $35 \mathrm{~m}$ in the CA section, whereas at well A1-36, in which a more complete sequence was drilled, it is nearly $360 \mathrm{~m}$ thick.

The Al Bayda Formation and Al Abraq Formation (Röhlich, 1974) typically crop out between the towns of Al Bayda and Al Abraq on the Al Bayda-Dernah highway. The Al Bayda Formation (Early Oligocene) is further subdivided into two members, the Shahat Marl and Algal Limestone (Kleinsmeide \& Van Den Berg, 1968). Lithologically, the lower unit of this formation consists of yellowish limestone and soft, argillaceous limestone interbeds, whereas the upper unit is made up of massive and thick-bedded, yellowish and hard limestone. The thickness of the Al Bayda Formation is $40 \mathrm{~m}$ in the CA section and $36 \mathrm{~m}$ in well Al-36. In the study area, the Al Abraq Formation (Early to Late Oligocene) is characterized by thickbedded and massive, yellowish limestone with intercalations of dolomitic limestone. This unit is missing in well $\mathrm{Al}-36$, whereas it is $22 \mathrm{~m}$ thick in the CA section.

The Al Faidiyah Formation (Pietersz, 1968) has its type locality near the village of Qaryat al Faidiyah, about $16 \mathrm{~km}$ south of Cyrene. This unit has a thickness of $6 \mathrm{~m}$ in the $\mathrm{CA}$ section, in which only the stratigraphically oldest (Upper Oligocene) beds crop out, and $300 \mathrm{~m}$ in A1-36 well, where the unit consists of its Early to Middle Miocene section. Lithologically, the Al Faidiyah Formation mainly consists of soft and dark grey, argillaceous limestone intergrading with hard and thick-bedded dolomitic limestone.

\section{MATERIALS AND METHODS}

A total of 50 samples from the $103 \mathrm{~m}$ thick CA section and 125 ditch cuttings samples from the nearly $700 \mathrm{~m}$ thick well A1-36 were processed for microfacies and foraminiferal analysis. During outcrop sampling, composition, sedimentary structures and macrofossil records were taken into account. Surface samples were collected at a maximum interval of $2.5 \mathrm{~m}$, although in critical intervals (i.e. lithological facies changes) they had a closer spacing. Ditch cuttings samples were taken at $5-6 \mathrm{~m}$ intervals. All samples were then processed for thin section preparations after a careful examination of each of the ditch samples to pick only in situ material and to avoid, whenever possible, the caving problem. In several intervals, however, materials from shallower parts of the borehole were picked on purpose, because the experience of one of us (RB) has shown that microfossil preservation from caved beds is often much better than that of in situ materials (see also Copestake, 1993). In most of these cases, particular characteristics of the microfacies allowed their proper horizon to be recognized. Many of the samples, with the exception of the hard lithologies, were crushed and disaggregated by hydrogen peroxide solution and washed through a $63 \mu \mathrm{m}$ sieve. Depending on the microfossil abundance, 
Foraminiferal distribution of Eocene-Miocene, NE Libya
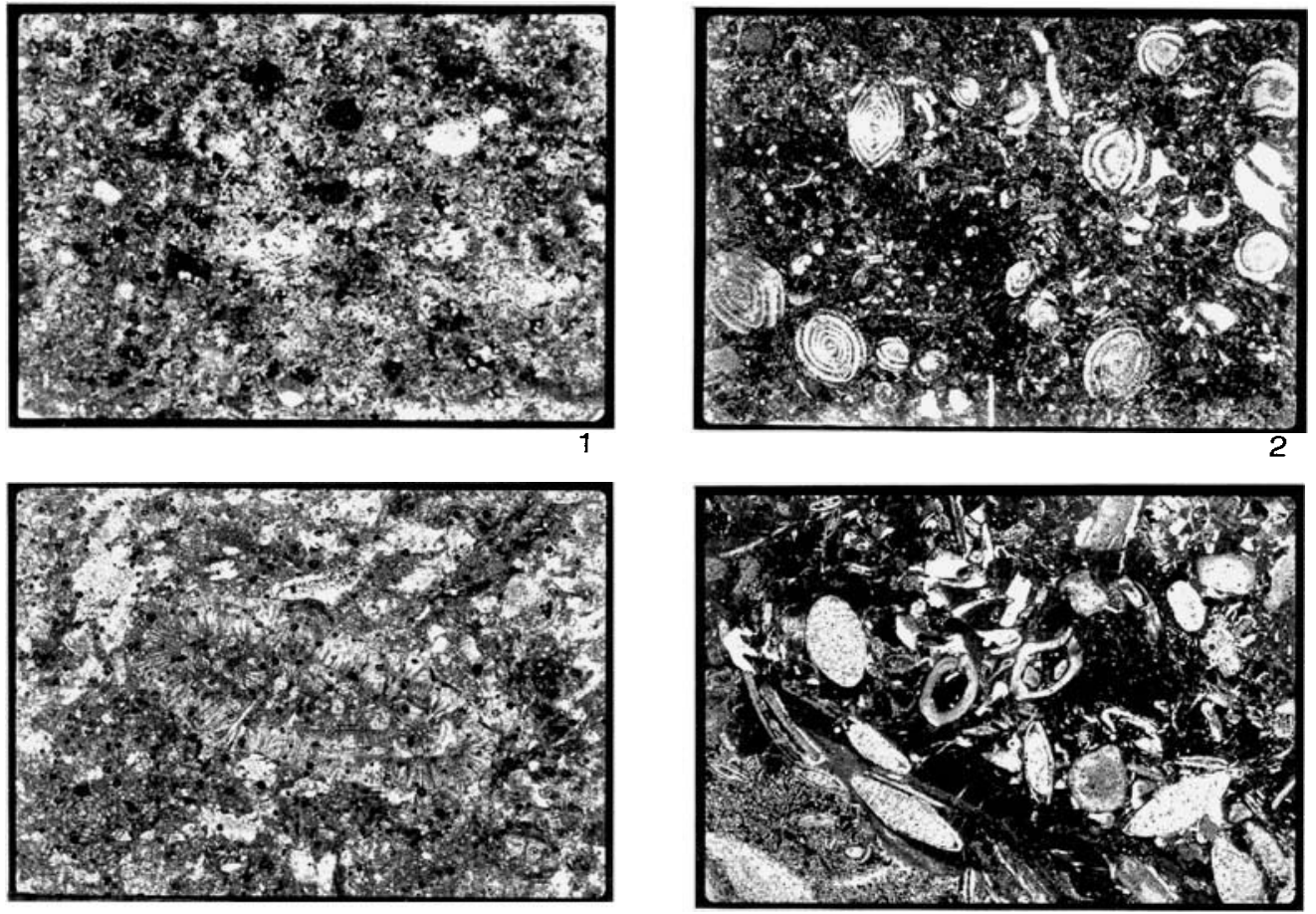

3

4
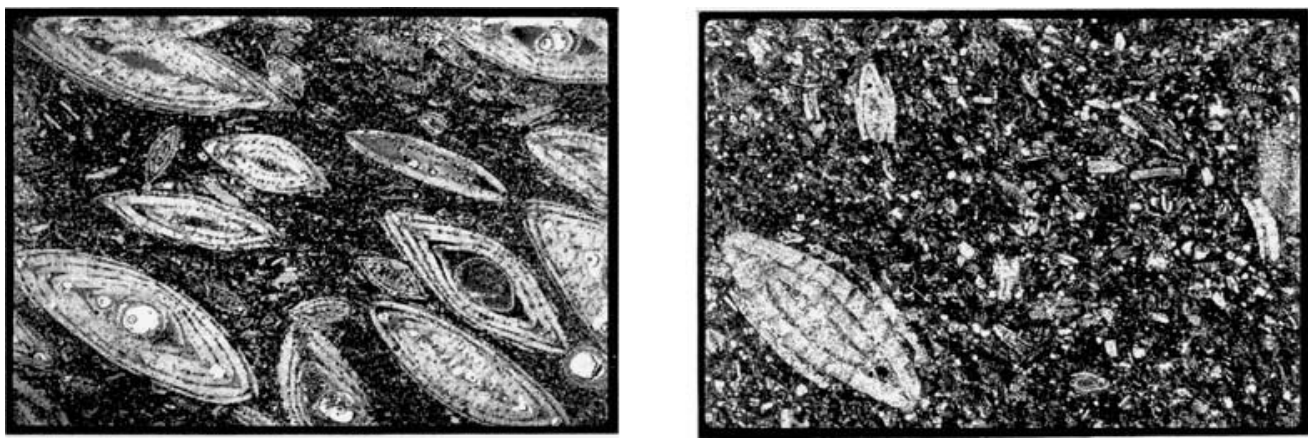

6
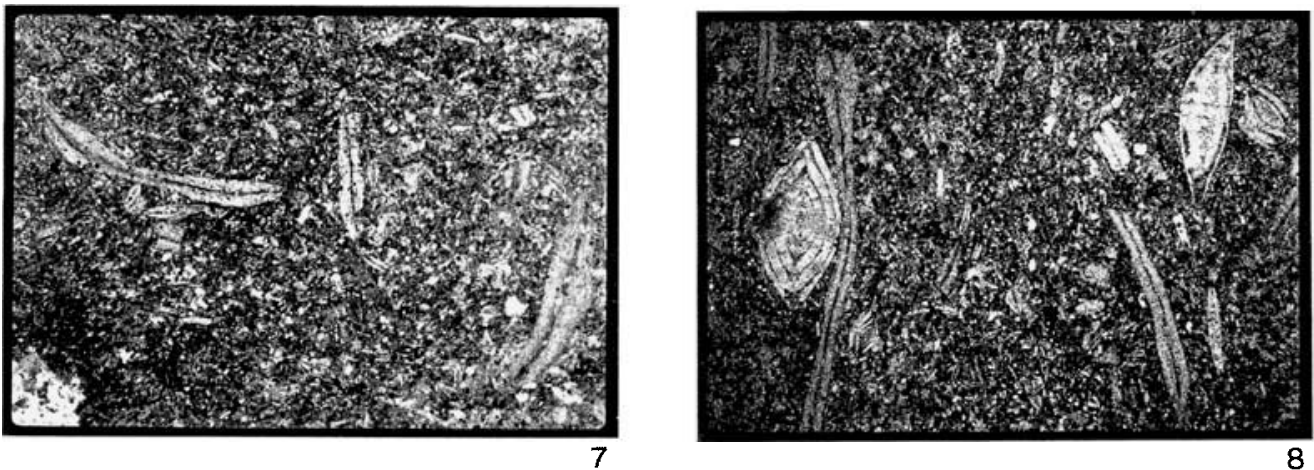

Explanation of Plate 1

fig. 1. General view of microfacies A, fine-grained, biodetrital and planktonic foraminiferal mudstone-wackestone. Well Al-36, lowermost part of Dernah Formation, $\times$ 16. fig. 2. General view of microfacies B, nummulitid wackestone with Sphaerogypsina sp. (top left) and fossil debris. CA section, lower part of Dernah Formation, $\times 2.1$. fig. 3. Microfacies B, axial section of Pellatispira sp.1 and equatorial section of Sphaerogypsina sp. (bottom right). CA section, lower part of Dernah Formation, $\times 6.9$. fig. 4. General view of microfacies B, packstone with pillared, small-sized Nummulites spp., echinoiderm remnants and serpulids. CA section, upper part of Dernah Formation, $\times 1.6$. fig. 5. General view of microfacies B, packstone with common A-forms of Nummulites sp.1. CA section, upper part of Dernah Formation, $\times 1.6$. fig. 6. General view of microfacies C, skeletal packstone with reworked (Eocene) discocyclinid and nummulitid debris. CA section, basal part of Shahat Marl Member, Al Bayda Formation, $\times 5.8$. fig. 7. General view of microfacies C, packstone with reworked Asterocyclina spp. and discocyclinid remnants. CA section, lower part of Shahat Marl Member, Al Bayda Formation, x3.2. fig. 8. General view of microfacies C, packstone with reworked Nummulites spp. and Asterocyclina spp. CA section, upper part of Shahat Marl Member, Al Bayda Formation, $\times 2.7$. 

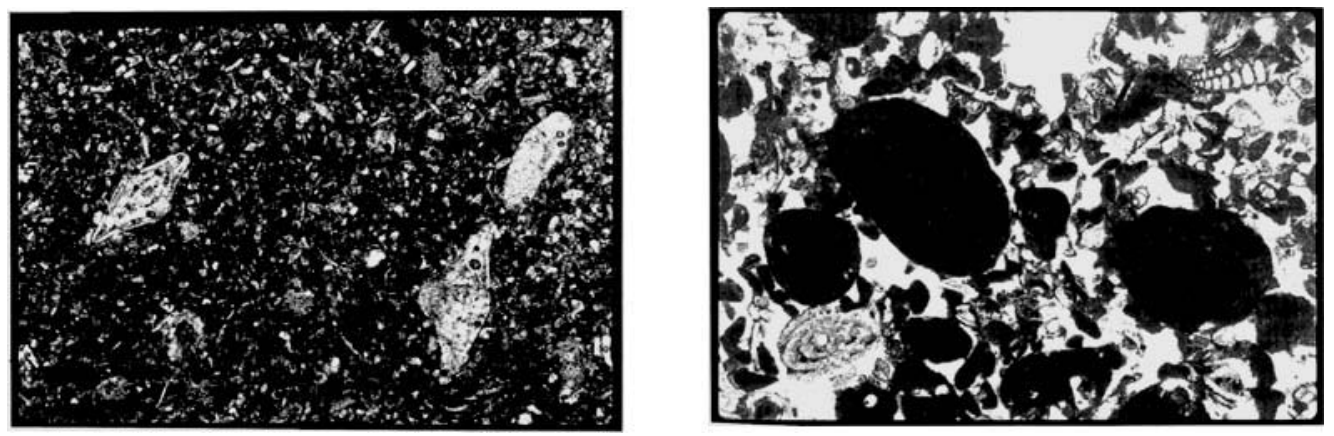

1

2
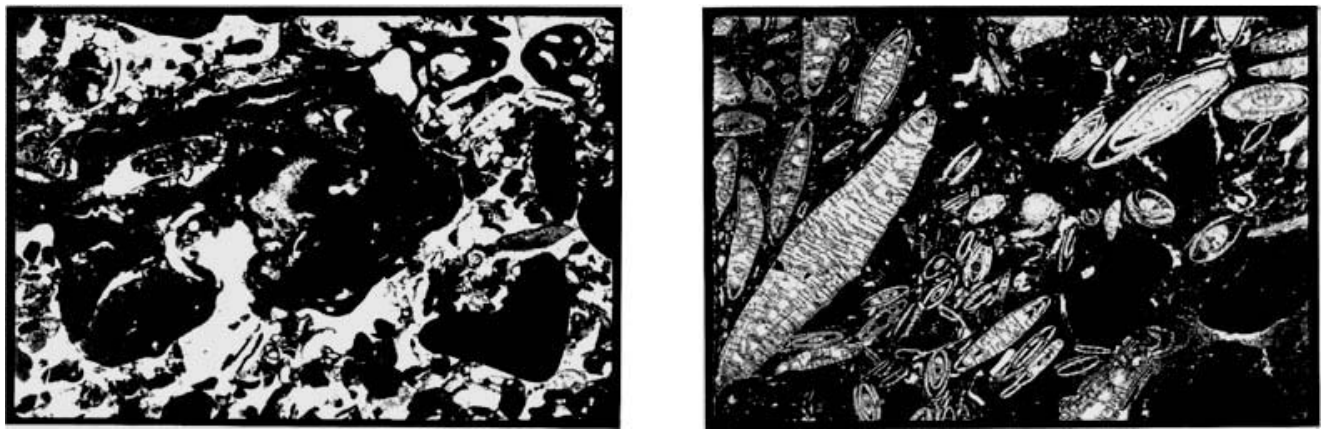

3

4
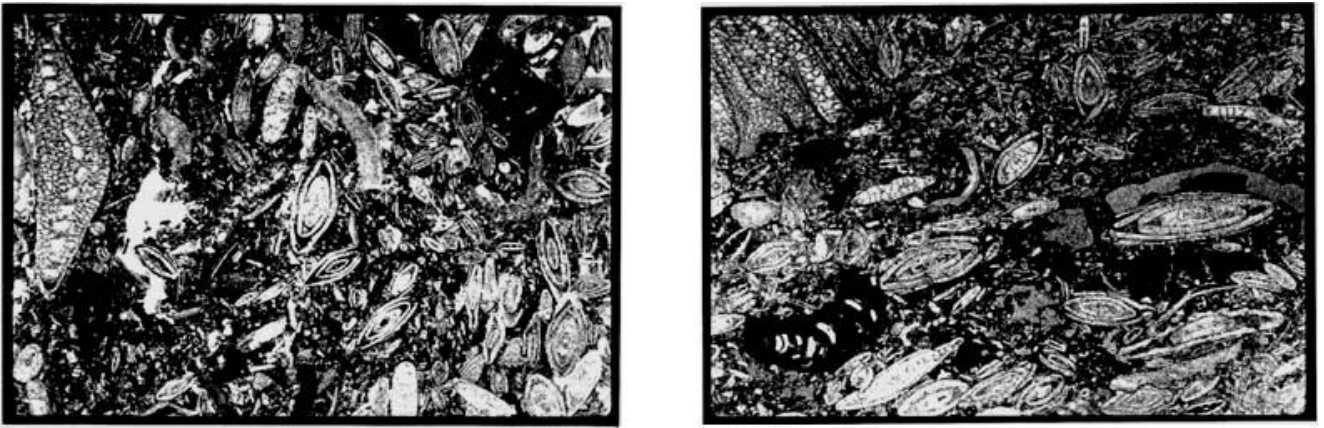

5

6
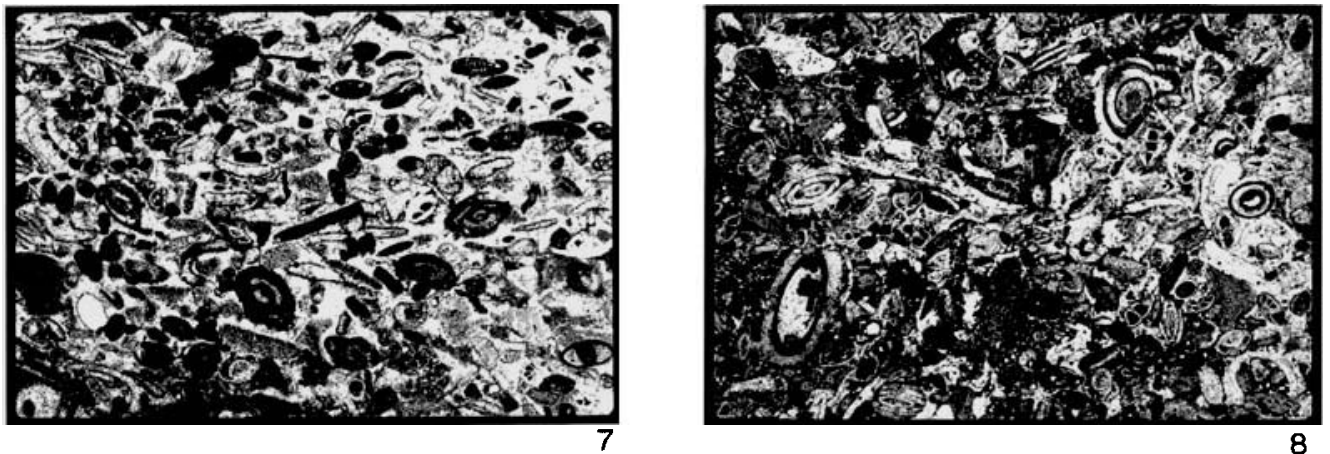

Explanation of Plate 2

fig. 1. General view of microfacies D, wackestone with small-sized, rare Nummulites spp. CA section, upper part of Shahat Marl Member, Al Bayda Formation, $\times 6.9$. fig. 2. General view of microfacies E, poorly sorted grainstone with nodular coralline algae (large, dark areas), rare Nummulites spp., textulariids, rotaliids, and echinoid remnants. CA section, lower part of Algal Limestone Member, Al Bayda Formation, $\times 4.2$. fig. 3. General view of microfacies E, grainstone with encrusted coralline algae, rotaliids and rare, small and thick-walled Nummulites spp. CA section, lower part of Algal Limestone Member of Al Bayda Formation, $\times 4.8$. fig. 4. General view of microfacies F, wackestone-packstone with Nummulites cf. fichteli (left side) and small-sized Nummulites spp. The dark areas are nodular coralline algae. CA section upper part of Algal Limestone Member, Al Bayda Formation, $\times 1.6 X 3$. fig. 5. General view of microfacies $F$, poorly sorted wackestone-packstone with Nummulites cf. fichteli (left side). Note the abundance of thick and small-sized Nummulites spp. CA section, upper part of Algal Limestone Member, Al Bayda Formation, $\times 1.6$. fig. 6. General view of microfacies F, poorly sorted nummulitid wackestone-packstone with Nummulites $\mathrm{cf}$. fichteli. CA section, upper part of Algal Limestone Member, Al Bayda Formation. Note the compaction and concentration of small-sized, thick Nummulites spp., coralline algae (dark areas) with conceptacles (bottom left) and other skeletal remnants, $\times 4.2$. fig. 7. General view of sub-microfacies $\mathrm{G}_{1}$, grainstone-packstone with porcelaneous foraminifera (miliolids), rotaliids, nummulitids, echinoid and coralline algae remnants. CA section, lower part of Al Abraq Formation, $\times 4.2$. fig. 8. General view of sub-microfacies $G_{1}$, packstone with common serpulids (bottom left and top right), coralline algae, rotaliids and recrystallized Nummulites spp. CA section, lower part of Al Abraq Formation, $\times 3.2$. 
Foraminiferal distribution of Eocene-Miocene, NE Libya
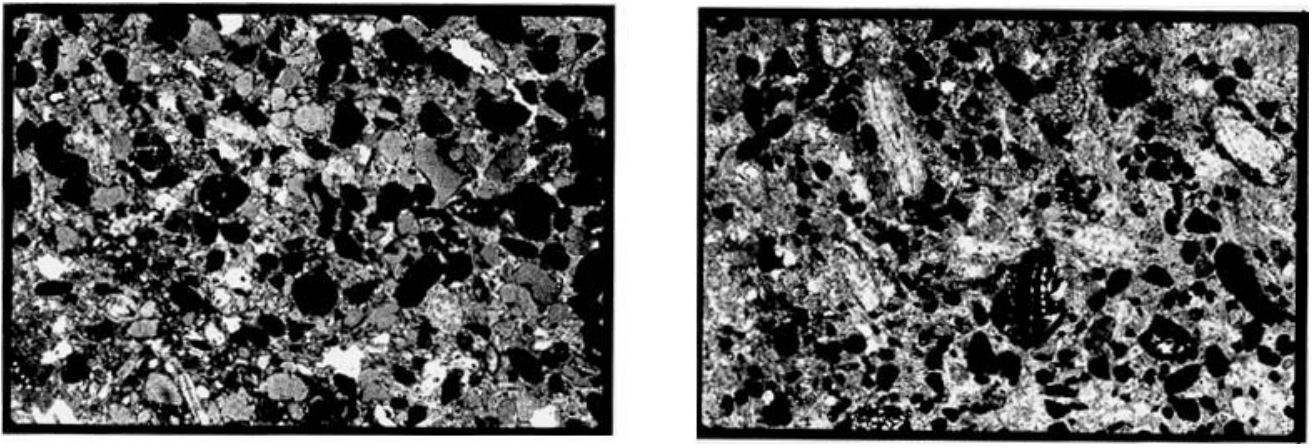

1

2
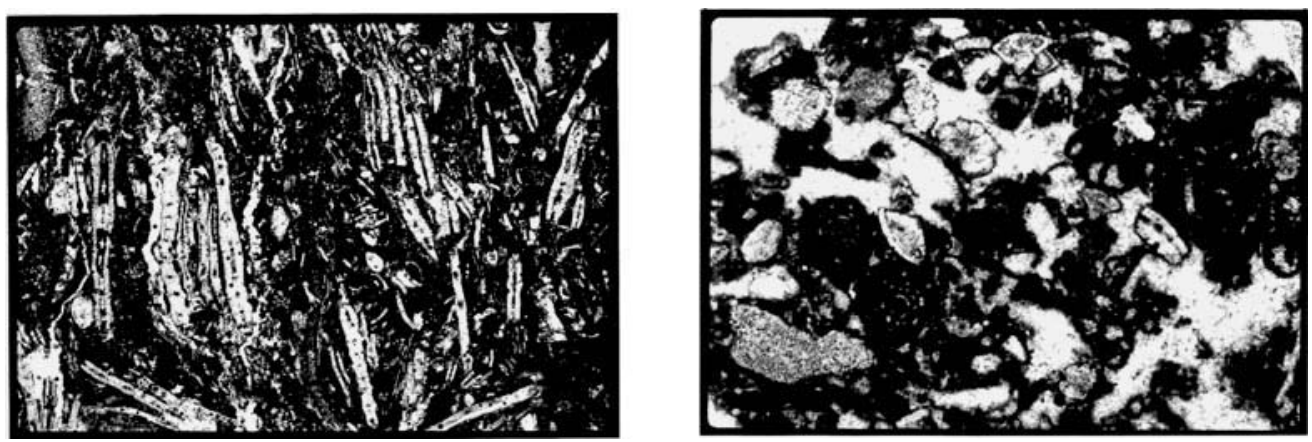

3

4
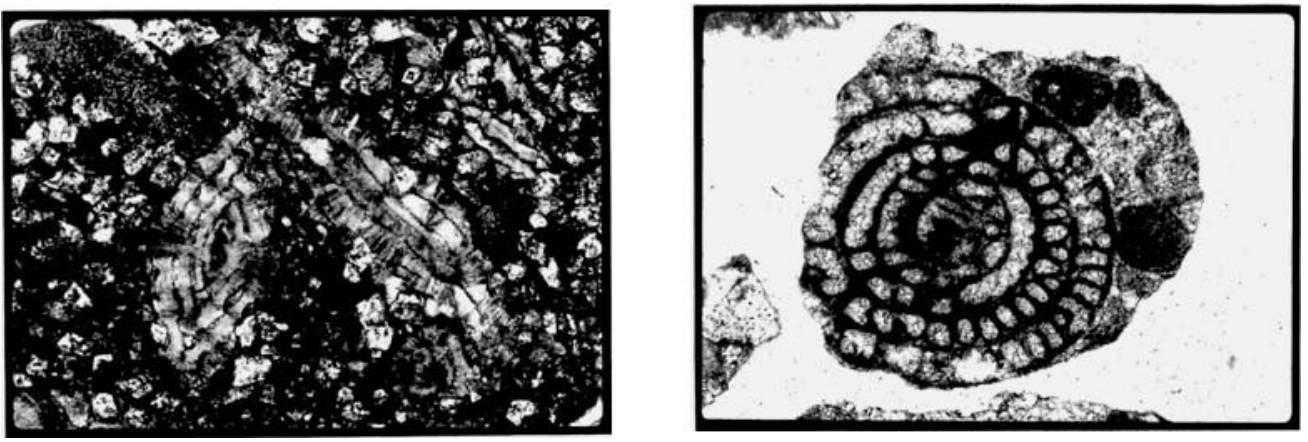

5
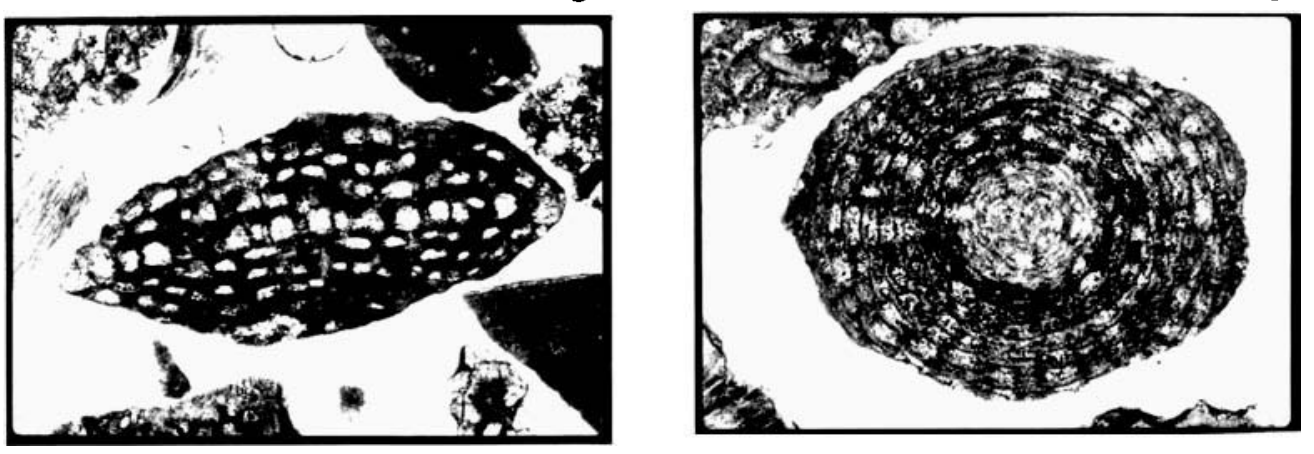

7

8

Explanation of Plate 3

figs. 1 and 2. General view of sub-microfacies $G_{2}$, glauconitic wackestone-packstone with abundant echinoid remnants (grey colour), and rare, small recrystallized Nummulites spp. CA section, upper part of Al Abraq Formation. Note the dominance of glauconite pellets (dark colour), $\times 3.2$. fig. 3 . General view of sub-microfacies $\mathrm{G}_{2}$, wackestone-packstone with Operculina spp. and scattered fragments of Miogypsina. CA section, uppermost part of Al Abraq Formation (Operculina bed), $\times 1$.6. fig. 4. General view of microfacies H, packstone-grainstone with common rotaliids, Borelis melo (left side) and miliolids. Well A1-36, middle part of Al Faidiyah Formation. Pelleted (faecal) patches have dark colour, $\times 9.5$. fig. 5. Nummulites cf. cuvillieri Sander, axial section. Well A1-36, Dernah Formation, $\times 11$.1. fig. 6. Borelis melo (Fichtel \& Moll), oblique section. Well A1-36, Al Faidiyah Formation, $\times 15.9$. fig. 7. Miogypsina sp. 1, longitudinal section. Well A1-36, Al Faidiyah Formation, $\times 11.1$. fig. 8. Sphaerogypsina sp.1, oblique section. Well A1-36, Dernah Formation, $\times 15.9$. 
from some tens to several hundreds benthic and planktonic foraminifera were picked per sample, identified and stored in cardboard slides. The study material, presently curated in the collections of the Capellini Palaeontological Museum (University of Bologna), will have a final repository in the Department of Earth Sciences of the University of Benghazi (Libya).

\section{PREVIOUS WORK}

Geological investigation in northeastern Libya started with Gregory (1911), who was the first to develop a systematic regional stratigraphy. Subsequently, Italian scientists, such as Stefanini (1923, 1935), Marchetti (1934) and Desio (1935, 1939), published comprehensive accounts mainly on stratigraphy, palaeontology and geomorphology.

The beginning of hydrocarbon exploration in Libya was crucial for the development of geological knowledge of Cyrenaica. In 1956 the first deep Libyan oil well was drilled on a surface structure recognized in the core of the Jabal al Akhdar. The first geological results derived from oil company activities are reported in the classic monograph Geology and Archaeology of Northern Cyrenaica (Barr, 1968a). The need to apply international stratigraphic rules and to simplify a complex stratigraphic nomenclature derived from the exploration activity of many oil companies produced a number of studies, including those by Kleinsmeide \& Van den Berg (1968), Barr \& Weegar (1972), Banerjee (1980) and Megerisi \& Mamgain (1980). These accounts set the foundation for the geological and stratigraphic work developed in northern Cyrenaica. Later publications on the stratigraphy and sedimentology of the region include those by El Hawat \& Salem (1987), Duronio et al. (1991) and El Hawat \& Shelmani (1993). In general, however, studies of the biostratigraphy and micropalaeontology of the Late Cretaceous and Tertiary of northern Cyrenaica are few and include those by Barr (1968b, 1972), Barr \& Hammuda (1971), El Khoudary (1976, 1977, 1980), Barr \& Berggren (1980) and Eliagoubi \& Powell (1980), together with limited micropalaeontological data from some of the rock units described here by Klen (1974), Röhlich (1974) and Zert (1974).

In spite of the quality and extent of the outcrop sections and over 40 years of intense hydrocarbon exploration, palaeoecologically oriented studies from northern Cyrenaica are absent, whereas they are numerous from elsewhere in the Tethyan middle Cenozoic.

\section{MICROFACIES DESCRIPTION}

The results of this study on the microfacies of the Cenozoic rocks from the Jabal al Akhdar contribute to our understanding of the depositional sequences and their correlation. The described microfacies are similar in definition and interpretation to those proposed by Wilson (1975) and Flügel (1982).

Microfacies from all the formations recognized in the field have been described and summarized in a number of associations (microfacies A to H, Fig. 2) (Plates 1-3). The ranges and observed occurrences of selected useful taxa from the biotic constituents of the microfacies are presented in Figs 3 and 4.

Microfacies associations show a large-scale cyclicity within the Oligocene rocks of the CA section. Oscillations of sea level and sedimentary gaps are evident in this outcrop and they are reflected in the alternation of microfacies typifying a relatively deep and open shelf (microfacies D) and others from a carbonate platform complex (microfacies C, E, F and G). This cyclicity pattern has not been recognized in well A1-36, where the Oligocene succession is incomplete and limited to the Shahat Marl Member of the Al Bayda Formation. Hence, microfacies $E, F$ and $G$ are recognized only in the $C A$ section (Algal Limestone Member of the Al Bayda Formation and Al Abraq Formation). Microfacies $H$ is recognized only in well Al-36, where it makes up the Early-Middle Miocene Al Faidiyah Formation. The microfacies associations present in the studied successions are described in the following sections.

\section{Microfacies A (nummulitid and planktonic foraminiferal mud- stone)}

Whitish to grey carbonates containing microfacies $\mathrm{A}$ are medium- to thick-bedded and are relatively soft. Microfacies A consists of mudstones with rare, fine-grained allochems. In well A1-36 this microfacies (Plate 1, fig. 1) becomes more argillaceous and the allochems show iron oxide impregnations. Microfacies A represents the lowermost part of the Dernah Formation and small-sized Nummulites $(<1 \mathrm{~cm})$, with a low abundance and diversity, and globigerinids are the main biotic constituents.

\section{Microfacies B (nummulitid and discocyclinid wackestone-pack- stone)}

Yellowish, thick-bedded to massive, hard carbonates contain microfacies B. Lithologically, wackestone dominates in the lower part of the interval (Plate 1, fig. 2), whereas packstone is the prevailing lithology in the middle and upper parts (Plate 1, figs 4 and 5). The matrix is medium- to coarse-grained, with local sparite patches. Micritic envelopes on skeletal remnants of nearshore origin are scarce. This microfacies comprises the lower and upper parts of the Dernah Formation. The assemblages are dominated by large-sized Nummulites spp. (up to $5 \mathrm{~cm}$ ) and Discocyclina spp. Coralline red algae, molluscs and echinoderms provide common biodetrital material, whereas small benthic foraminifera are usually rare. Common foraminiferal constituents include Nummulites gizehensis, $N$. cf. cuvillieri, $N$. cf. subdiscorbinus, N. cf. fabianii, Assilina spp., Sphaerogypsina sp. 1, and Pellatispira sp. 1 (Plate 1, fig. 3). In the shaly intervals that regularly interbed the carbonates in the Dernah Formation of well A1-36, assemblages with Rotalia mexicana and Lenticulina texana have been recovered.

\section{Microfacies C (nummulitid packstone)}

Microfacies $C$ has been described in yellowish and relatively soft, thin- to medium-bedded marly carbonates from the lower part of the Shahat Marl Member (Al Bayda Formation). Its lithology can be summarized as micritic packstone with a fine- to coarse-grained matrix that largely consists of skeletal remnants of echinoderm, mollusc, and bryozoan origin. In the basal beds of the Shahat Marl Member of the CA section, this microfacies contains abundant reworked (Eocene) discocyclinids and nummulitids (more than $90 \%$ of the total assemblage) (Plate 1 , figs $6-8$ ). In the biodetrital material, syntaxial cement rims, coated grains and traces of iron oxide are scarce. Globigerinids are rare, but persistent, constituents. The bioclasts in well A1-36 include foraminifera such as Nummulites cf. fichteli, $N$. cf. vascus 


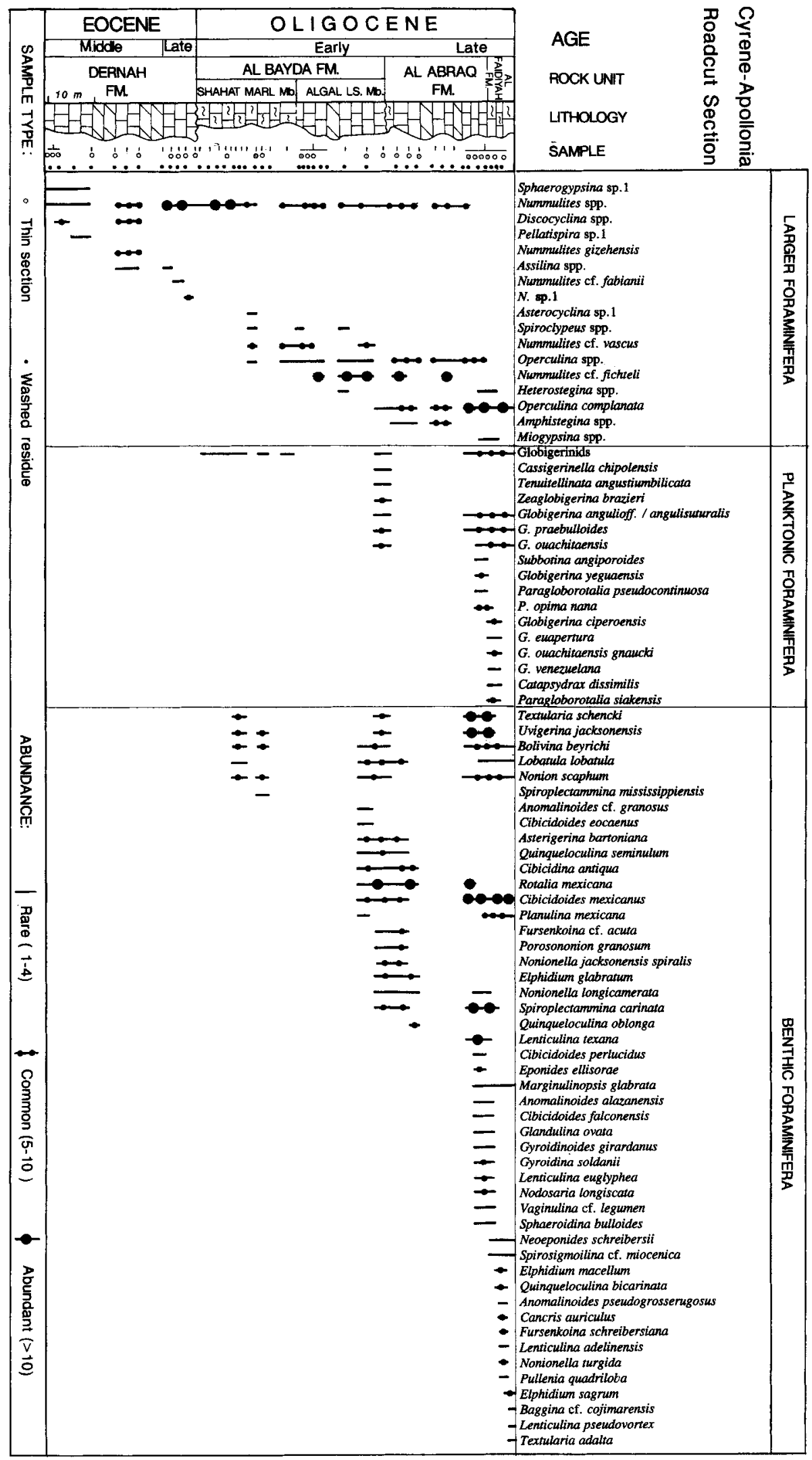

Fig. 3. Distribution of selected foraminiferal taxa from the Cyrene-Apollonia (CA) section. 


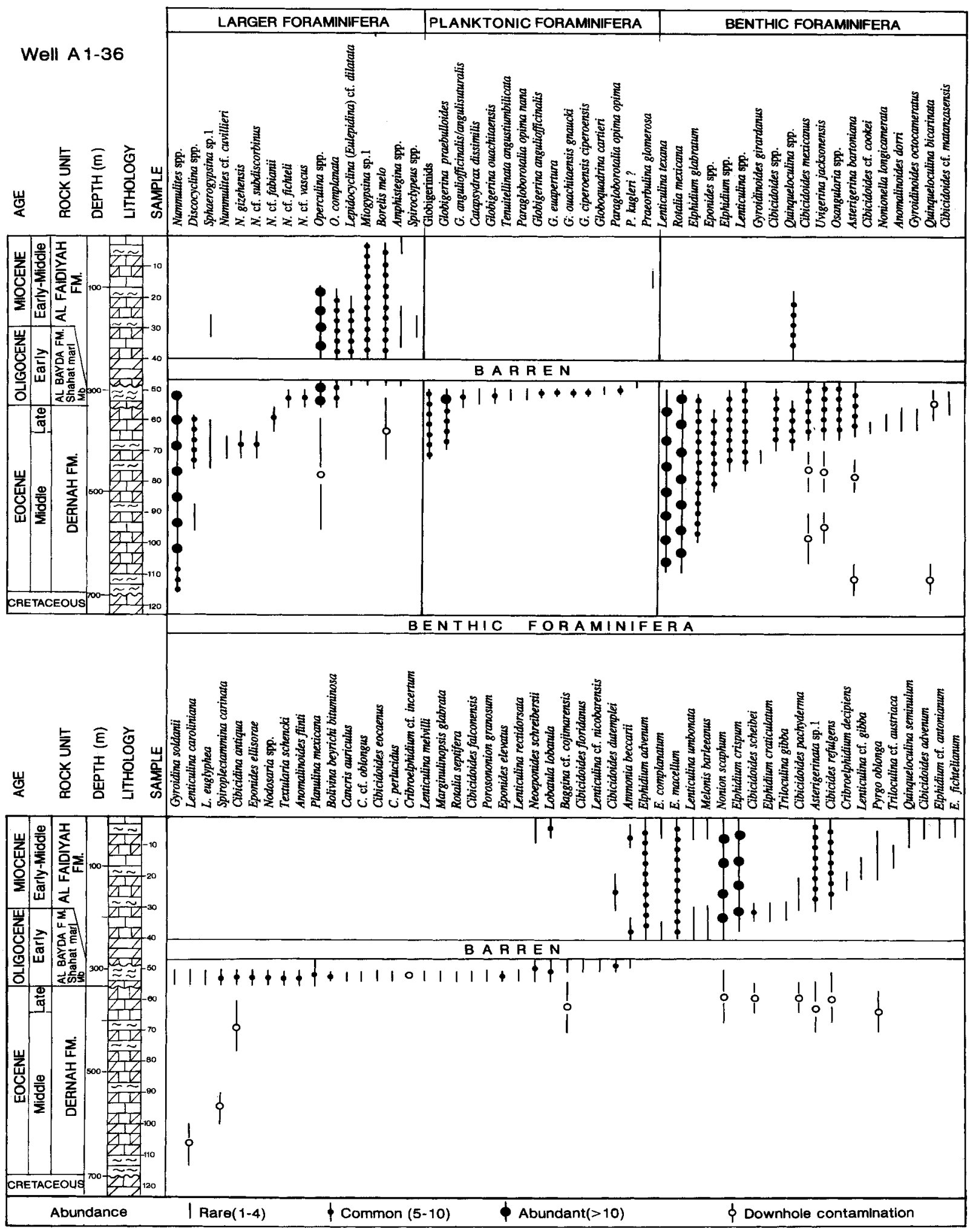

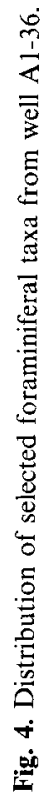


and Operculina complanata.

Microfacies D (planktonic foraminiferal mudstone-wackestone) Marly carbonates containing microfacies D are soft, medium- to thick-bedded and yellowish to brownish. In the Shahat Marl Member, this microfacies alternates with microfacies $\mathrm{C}$. This mainly argillaceous mudstone and wackestone has a fine-grained matrix (Plate 2, fig. 1), and micritization of allochems and iron oxide are common. The assemblage consists of common globigerinids, rotaliids, and rare nummulitids. Mollusc and echinoid debris and smooth-shelled ostracods are also common components, whereas small benthic foraminifera, such as textulariids and small rotaliids, are accessory constituents. Abundant and diverse assemblages of small foraminifera have been recovered in well A1-36 from marly rocks assigned to this microfacies (Fig. 4).

Microfacies E (coral-algal and nummulitid packstone-grainstone) Microfacies $\mathrm{E}$ has been described from hard, massive to thickbedded and whitish to yellowish carbonates. It comprises the lower part of the Algal Limestone Member (Al Bayda Formation). Poorly sorted packstone and grainstone of microfacies $E$ have a fine- to medium-grained matrix and prevailing sparry calcite cement (Plate 2, figs 2 and 3). Structures of diagenetic origin, such as conceptacal and geopetal structures, and syntaxial overgrowths, have frequently been observed. The biotic content shows abundant nodular forms of coralline red algae and encrusting forms belonging to the genera Lithophyllum and Lithothamnion. The skeletal component also includes fragments or entire shells of nummulitids, operculinids, heterosteginids, amphisteginids, ostracods, corals, bivalves, gastropods, echinoids and bryozoa with variable proportions. Small foraminifera of attached and free mode of life locally occur.

\section{Microfacies F (nummulitid packstone-wackstone)}

Microfacies $F$ has been described in white to grey, hard and thick-bedded carbonates. This microfacies is from the upper part of the Algal Limestone Member. The lithology mainly consists of packstone and wackestone in which cements range from micrite to sparite (Plate 2, figs 4-6). Micritization of allochems of diagenetic origin is common and other diagenetic features, such as those observed for microfacies $\mathrm{E}$, are persistent. The biotic components are mainly poorly sorted and thick-walled Nummulites ( $N$. cf. fichteli). Compared with microfacies E, this microfacies contains fewer coralline algae and, locally, they are absent. The abundance of foraminifera typifying soft substrates, epiphytes and planktonic foraminifera enables a further distinction from microfacies $\mathrm{E}$. Ostracods and echinoid, bryozoan and mollusc debris make up the remaining skeletal components.

\section{Microfacies G}

The amount of siliciclastic materials and glauconite pellets has been used to separate two distinct sub-microfacies in microfacies $\mathbf{G}$.

Sub-microfacies $G_{1}$ (miliolid and nummulitid wackestone-packstone). Whitish to yellowish carbonates from which submicrofacies $G_{1}$ has been described are thick-bedded and relatively soft. This microfacies represents the lower part of the Al Abraq Formation and lithologically mainly consists of bioclastic wackestone and packstone (Plate 2, figs 7 and 8). The matrix is medium- to coarse-grained with poorly sorted concentrations of bioclast remnants. Most of the original bioclasts, however, have been completely dissolved and moulds outlined by a thin micrite envelope were then filled by sparry calcite cement. Other diagenetic features, such as conceptacal structures, syntaxial overgrowths, geopetal fabric (in gastropod shells) and bioclast recrystallization, are commonly observed. There is often evidence of partial secondary dolomitization. The foraminiferal component includes abundant miliolids and nummulitids and, with fewer numbers, amphisteginids, operculinas and rotaliids. The bioclastic component consists of coralline red algae (e.g. Lithophyllum spp.), bivalves, gastropods, bryozoa, echinoids and serpulid tubes.

Sub-microfacies $G_{2}$ (nummulitid and coiled vaginulinid wackestone-packstone).

Yellowish to brownish carbonates containing sub-microfacies $\mathrm{G}_{2}$ are hard and thick-bedded. They comprise the upper part of the Al Abraq Formation. The lithology and skeletal components are similar to the previous sub-microfacies, from which submicrofacies $G_{2}$ may be primarily distinguished because it contains sand-sized siliciclastic materials and light green glauconite pellets that are abundant throughout the interval (Plate 3, figs 1 and 2). The remainder of the sediment is made up of recrystallized bioclasts set in a fine micritic matrix. Compared with sub-microfacies $\mathrm{G}_{1}$, thick-shelled Operculina complanata, variable numbers of Miogypsina spp., coiled vaginulinids, agglutinated and miliolid taxa, and the up-section reduction of Nummulites spp. characterize the biotic component of submicrofacies $G_{2}$. The top of this sub-microfacies in the CA section (top of the Al Abraq Formation) is characterized by a high concentration of Operculina tests arranged parallel to bedding (Plate 3, fig. 3).

Microfacies $\mathbf{H}$ (alveolinid and miogypsinid packstone-grainstone) Carbonates in which microfacies $\mathrm{H}$ is represented are hard, thick-bedded to massive and are interbedded with marls and dolomitic limestones. This microfacies comprises the middle and upper parts (Miocene) of the Al Faidiyah Formation. The lithology mainly consists of pelleted (faecal) packstone and grainstone (Plate 3, fig. 4) in which rhombs of dolomite, locally impregnated by iron oxide, are common. The cement is mainly sparite in which the crystal size and irregular shape suggest neomorphic fabrics or crystalline granular texture. Geopetal structures and leaching of bioclasts also occurs. The biotic component consists of miliolids, elphidiids, nonioniids, miogypsinids, alveolinids and ostracods. Debris of larger foraminifera, including Eulepidina, Operculina, Miogypsina, Amphistegina, Spiroclypeus, Heterostegina and Borelis, make up most of the allochems present.

\section{FORAMINIFERAL ASSEMBLAGES AND PALAEOBIO- GEOGRAPHIC AFFINITIES}

The washed residues obtained from the soft-rock intervals of the study successions enable the investigation of abundant and diverse foraminiferal assemblages. About 150 species and subspecies, belonging to more than 65 genera, have been identified. The preservation is variable, although it is generally 
poor and only locally good. In a few instances the preservation is so poor as to prevent a proper identification of the foraminiferal taxa. Barren intervals are present and they may reflect a very poor preservation potential. Pyritization and calcification as diagenetic processes frequently occur in some stratigraphic levels. On the whole, the assemblages show a dominance of the calcareous benthic foraminifera (Rotaliina), with an average of $70-90 \%$ of the total assemblage, whereas porcelaneous (Miliolina) and agglutinated taxa (Textulariina) average $0-20$ and $0-5 \%$, respectively. Planktonic foraminiferal abundance is usually low (up to $10 \%$ ). The simple diversity is generally low, with the exception of those intervals assigned to the foreslope and open platform, and ranges between 5 and 30 taxa/sample.

The bulk of the assemblages is generally represented by a very limited number of dominant taxa. This has also been observed in instances of high simple diversity, which is due to the high number of accessory species. Comparison among the foraminiferal assemblages recovered in the different lithostratigraphic units has shown that the species proportions strikingly change and the dominant species, usually large in size, may vary from sample to sample, probably reflecting changes in the preservation potential.

In a number of species, including Lenticulina texana (Plate 4, figs 1 and 2), Cibicidoides mexicanus, Lobatula lobatula, Nonion scaphum, Cibicidina antiqua, Nonionella longicamerata and $N$. turgida (Plate 4, fig. 4), different morphotypes can be distinguished. Common to abundant genera represented by more than one species include Nummulites, Operculina, Nonion, Nonionella, Rotalia, Eponides, Ammonia, Cibicidoides, Lenticulina, Elphidium, Quinqueloculina, Triloculina, Globigerina and Paragloborotalia.

Larger foraminifera have a low diversity throughout the studied successions, although they are abundant, especially in the Eocene interval. In the Late Eocene, reticulate Nummulites ( $N$. cf. fabianii) are common; they were replaced in the Oligocene by $N$. cf. fichteli and by striate species including $N$. cf. vascus. In the Oligocene and Miocene intervals, larger foraminifera are less diverse and less abundant.

The Palaeogene foraminiferal assemblages of northern Cyrenaica show variable degrees of similarity with those reported in shelf settings of the Atlantic (Caribbean) and Indo-Pacific palaeobiogeographic provinces. Taxonomic similarities in the Palaeogene larger and smaller foraminiferal assemblages between the above regions and the Mediterranean are well documented and confirm the persistence of biogeographic relationships during the early Cenozoic. These were lost in the Early-Middle Miocene because of the interruption of the marine connections (between the Mediterranean and IndoPacific) and the changing climate (between Mediterranean and Caribbean).

Since the Palaeocene, the smaller benthic foraminifera of Libya and Egypt have their closest affinities with the Gulf Coast and Trinidad assemblages (Midway-type faunas) (Berggren \& Phillips, 1971). Similarly, the Middle Eocene (Barr \& Berggren, 1980) and Late Eocene-Oligocene (this study) Cyrenaican assemblages show significant degrees of similarity with those from the Gulf Coast and Caribbean (Bolli et al., 1994), northern Italy (Di Napoli Alliata, 1953), the Hungarian Basin (Sztràkos, 1979, 1982) and Belgium (Batjes, 1958). However, these taxonomic comparisons are somewhat limited by the facies (carbonate or terrigenous) constraints, which may alter the composition of assemblages or induce diachroneities (e.g. the Middle Eocene Jackson-type faunas from Cyrenaica; Barr \& Berggren, 1980).

Compared with the larger foraminifera from the Indo-Pacific (Adams, 1967, 1970; Clarke \& Blow, 1969), the Cyrenaican assemblages, as well as other northern Africa assemblages, show marked similarities. They seem to be almost cosmopolitan at the generic level, whereas they show different degrees of endemism at the species level. For example, faunal isolating mechanisms are documented in the Tethyan realm. As pointed out by Schaub (1983), during the early Cenozoic the northern Tethyan (Pyrenees, Alps, Crimea and Iran) species of Nummulites differed from those of the southern Tethyan margin (northern Africa) because of an alleged deep-sea barrier that separated the two Tethyan margins, preventing an efficient communication among the neritic biota. Nummulites gizehensis, for example, one of the southern species, is well known from northern Africa and the Arabian Peninsula (Schaub, 1983; Racey, 1994), but not in Europe, although $N$. lyelli, the last member of this phylogenetic lineage, is one of the most characteristic species of the uppermost Middle Eocene of northern Italy (Schaub, 1983).

\section{BIOSTRATIGRAPHIC RESULTS AND PROBLEMS}

Lower to middle Tertiary deposits predominantly consisting of shallow marine carbonates are widespread in northeastern Libya and throughout the Tethyan realm. In biostratigraphic practice their abundant larger foraminiferal assemblages have been extensively used and, since the work of Clarke \& Blow (1969),

Explanation of Plate 4

figs 1 and 2. Lenticulina texana (Cushman \& Applin), apertural and lateral views. Well A1-36, lower part of Shahat Marl Member, Al Bayda Formation, $\times 37$. fig. 3. Textularia schencki Cushman \& Valentine, lateral view. CA section, upper part of Al Abraq Formation, $\times 50$. fig. 4 . Nonionella turgida (Williamson), lateral view. CA section, lower part of Al Faidiyah Formation, $\times 50$. figs 5 and 6. Nonionella jacksonensis spiralis Bandy, lateral views. CA section, lower part of Al Abraq Formation, $\times 100$. fig. 7. Uvigerina jacksonensis Cushman, lateral view. Well A1-36, lower part of Shahat Marl Member, Al Bayda Formation, $\times 75$. fig. 8. Spiroplectammina carinata (d'Orbigny), lateral view. CA section, upper part of Al Abraq Formation, $\times 50$. fig. 9. Fursenkoina schreibersiana (Czjzek), lateral view. CA section, lower part of Al Faidiyah Formation, $\times 50$. figs 10 and 11. Neoeponides schreibersii (d'Orbigny), lateral views. CA section, upper part of Al Abraq Formation, $\times 25$. figs 12 and 13 . Nonion scaphum (Fichtel \& Moll), lateral and apertural views. Well A1-36, lower part of Shahat Marl Member, Al Bayda Formation, $\times 50$. fig. 14. Marginulinopsis glabrata (Cushman), lateral view. Well A1-36, lower part of Shahat Marl Member, Al Bayda Formation, $\times 50$. figs 15-17. Cibicidoides mexicanus (Nuttall), lateral and apertural views. Well A1-36, lower part of Shahat Marl Member, Al Bayda Formation, $\times 37$. fig. 18. Bolivina beyrichi bituminosa Spandle, lateral view. Well A1-36, lower part of Shahat Marl Member, Al Bayda Formation, $\times 75$. fig. 19 and 20. Cibicidoides pachyderma (Rzehak), lateral views. Well A1-36, lower part of Shahat Marl Member, Al Bayda Formation, $\times 50$. figs 21 and 22. Elphidium glabratum Cushman, apertural and lateral views. CA section, lower part of Al Abraq Formation, $\times 37$. 

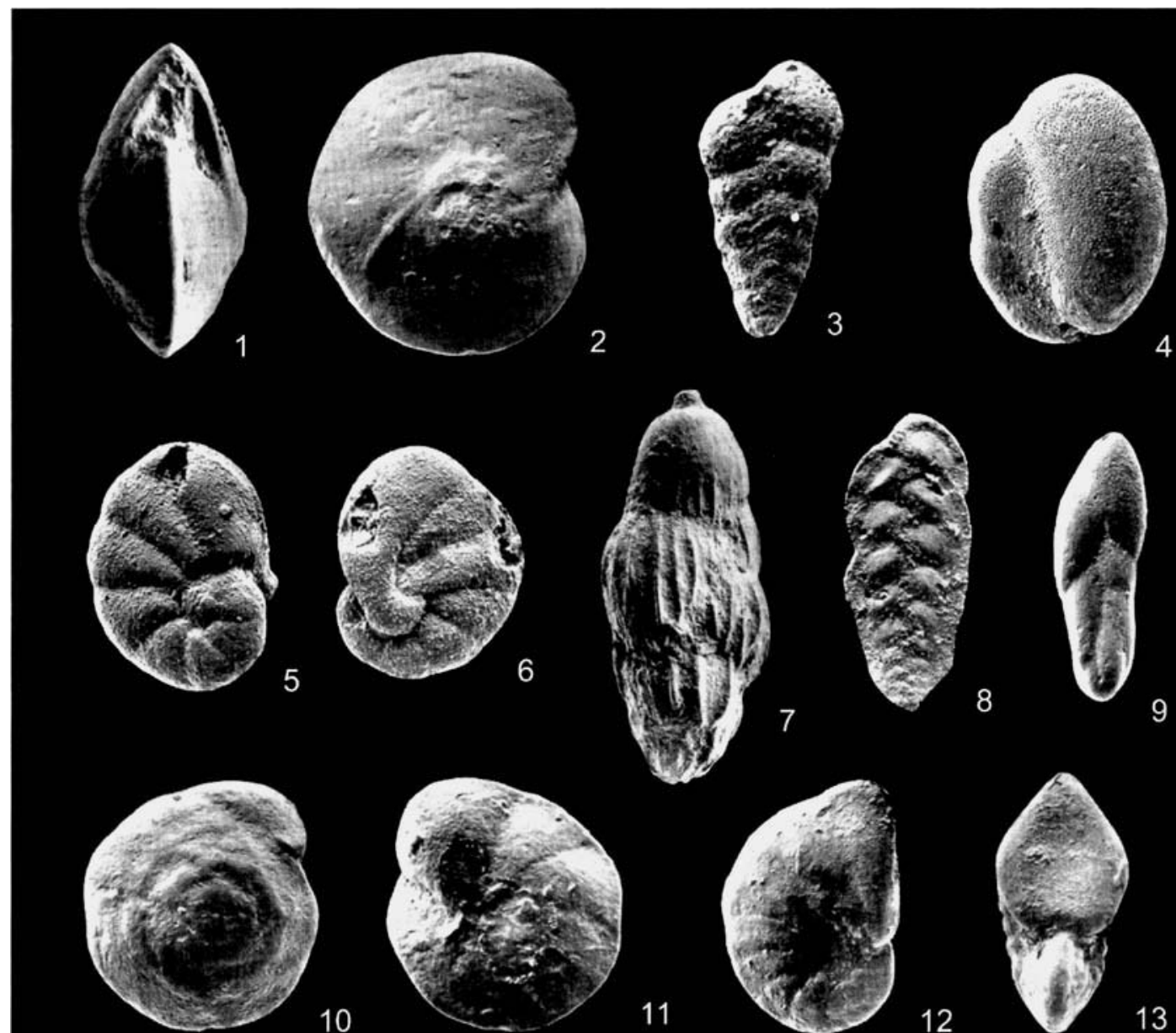

10
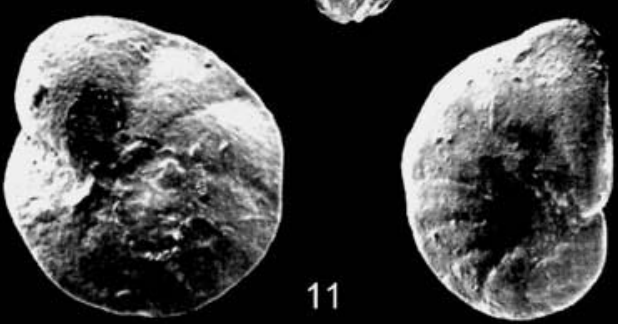

12

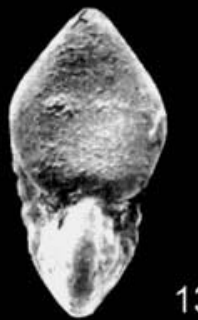

9
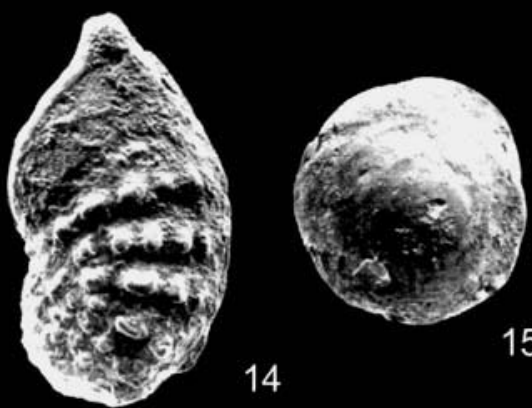

15
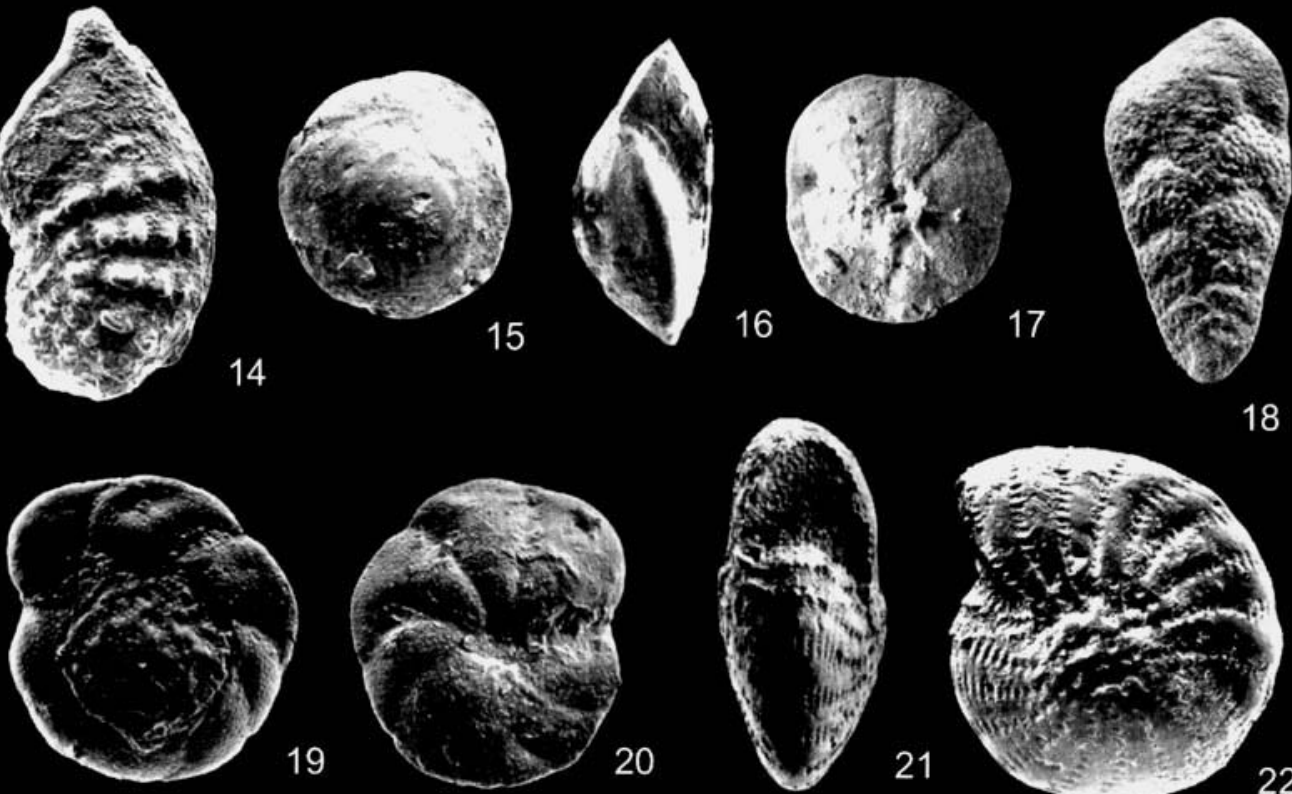
there have been numerous attempts to correlate larger foraminiferal zonations with those established by means of planktonic groups. However, because such rock types mostly contain facies-related fossil assemblages, correlations with standard zonations are often difficult. A further complication derives from the rarity of planktonic foraminifera in shallow water carbonates. Considering the discontinuous planktonic foraminiferal distribution presented in Figs 3 and 4, an obvious relationship between lithotypes and planktonic abundance can be recognized in this study. The prevalence of surface and intermediate dwellers and the absence of age-diagnostic deepwater dwellers is a further limitation related to the known planktonic foraminiferal depth stratification. Elsewhere, in areas having facies associations including both shallow neritic and pelagic settings (e.g. Chapronière, 1980; Benjamini, 1995), fairly accurate correlations have been established with plankton-based zonations.

The use of the Letter classification in the studied successions (Fig. 2), in the revised version proposed by Adams $(1970,1984)$ for the Indo-Pacific region, is based on the biotic similarities that existed throughout the Tethyan domain during the early and middle Cenozoic. Especially in rocks prior to the Upper Eocene, several phyletic lineages of larger foraminifera provide a means of large-scale correlation. Actually, from the Late Eocene to Miocene the increasing differentiation between western Tethys (Mediterranean) and Indo-Pacific (Adams, 1967, 1984), combined with slower rates of evolution in a number of larger foraminiferal groups (Herb \& Hekel, 1973), reduced their potential as biostratigraphic and correlation tools.

In the present account, the limited biostratigraphic data obtained because of the facies control on the fossil range and abundance restricts the application of a formal zonal scheme and the use of quantitative or semi-quantitative methods of biostratigraphic correlation. Moreover, the development of a locally applicable zonation requires some confirmation of its lateral extent through studies on other biostratigraphically suitable sections. In spite of the complications arising from facies changes and stratigraphic gaps, the analysis of the distribution charts (Figs 3 and 4) indicate that every lithostratigraphic unit exhibits a distinctive age-related microfossil content. In this account, age determinations by means of nummulitids are based on the ranges by Clarke \& Blow (1969), Adams (1970), Blondeau (1972), Schaub (1981), Adams et al. (1983) and Racey (1995). The biostratigraphic data are summarized in the following sections.

\section{Middle Eocene}

The deposits of the lower and middle part of the Dernah
Formation have been ascribed to the Middle Eocene (Zone $\mathrm{Ta}_{3}$ of Adams, 1970). This interval exhibits a rather monotonous and poorly diverse microbiotic content where nummulitids dominate. Because the attempts to extract free specimens other than larger foraminifera from this hard limestone was unsuccessful, we primarily based our analysis on thin sections. The record of large-sized nummulitids, including Nummulites gizehensis, allows this interval to be characterized. Well known from Middle Eocene assemblages in southern Mediterranean regions (Schaub, 1981; Boukhary \& Hussein-Kamel, 1993), the large nummulitids are frequent at the top of the Middle Eocene Dernah Formation of the studied sections, where they are associated with $N$. cf. cuvillieri (Plate 3, fig. 5), and $N$. cf. subdiscorbinus. Discocyclina spp., Assilina spp., Sphaerogypsina sp.1 (Plate 3, fig. 8) and Pellatispira sp.1 (Plate 1, fig. 3) also occur in this interval. The top of the Middle Eocene is defined by the last occurrence of $N$. gizehensis and associated taxa.

\section{Late Eocene}

This interval comprises the upper part of the Dernah Formation. Upper Eocene rocks have been primarily recognized through the occurrence of a nummulitid assemblage including the Priabonian Nummulites cf. fabianii. This time interval can be correlated with Zone $\mathrm{Tb}$ of Adams (1970). Similar to the underlying interval, the biotic component has low diversity and larger foraminifera, rotaliids and coiled vaginulinids comprise much of the assemblages. The analysis of washed sample residues yielded several small benthic foraminifera, Late Eocene-Oligocene in age, such as Asterigerina bartoniana, Elphidium glabratum (Plate 4, figs 21 and 22), Lenticulina texana, Rotalia mexicana and Uvigerina jacksonensis (Plate 4, fig. 7). The Oligocene Al Bayda Formation rests disconformably on the Dernah Formation with a recognized stratigraphic gap in the well A1-36 succession.

\section{Oligocene}

The Oligocene deposits of the CA section are referred to the $\mathrm{Al}$ Bayda Formation, Al Abraq Formation and to the lower part of the Al Faidiyah Formation, whereas in well A1-36 they are limited to the lower member (Shahat Marl) of the Al Bayda Formation. This lower member provided a microfossil content significantly different in the two successions investigated. Although in outcrop the assemblages are still dominated by nummulitids, associated with limited numbers of small benthic taxa and reworked Eocene elements (Discocyclina and Nummulites), in well A1-36 the Shahat Marl yielded abundant and diverse foraminiferal assemblages, mostly recovered from the washed sample residues. These include planktonic foraminiferal

\section{Explanation of Plate 5}

figs 1 and 2. Praeorbulina glomerosa (Blow), Well Al-36, upper part of Al Faidiyah Formation, $\times 75$. figs 3 and 4. Globigerina praebulloides Blow, umbilical and spiral views. Well A1-36, lower part of Shahat Marl Member, Al Bayda Formation, $\times 100$. fig. 5. Cassigerinella chipolensis (Cushman \& Ponton), spiral view. CA section, lower part of Al Abraq Formation, $\times 175$. figs 6--8. Zeaglobigerina brazieri (Jenkins), umbilical, edge and spiral views. CA section, lower part of Al Abraq Formation, $\times 100$. fig. 9. Catapsydrax dissimilis (Cushman \& Bermudez), umbilical view. Well A1-36, lower part of Shahat Marl Member, Al Bayda Formation, $\times 100$. figs 10--12. Globigerina ouachitaensis gnaucki Blow \& Banner, umbilical, edge and spiral views. Well A1-36, lower part of Shahat Marl Member, Al Bayda Formation, $\times 75$. figs 13 and 17. Globigerina venezuelana Hedberg, umbilical and spiral views. CA section, lower part of A1 Faidiyah Formation, $\times 75$. figs 14 and 18 . Globigerina ciperoensis Bolli, umbilical and spiral views. Well A136, lower part of Shahat Marl Member, Al Bayda Formation, $\times 100$. figs 15 and 16. Paragloborotalia siakensis (LeRoy), umbilical and spiral views. CA section, lower part of Al Faidiyah Formation, $\times 50$. figs 19-21. Globigerina euapertura Jenkins, umbilical, edge, and spiral views. Well A1-36, lower part of Shahat Marl Member, Al Bayda Formation, $\times 75$. 


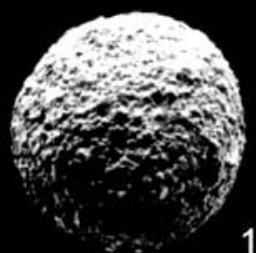

1

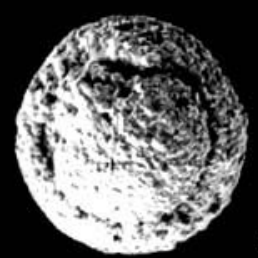

2
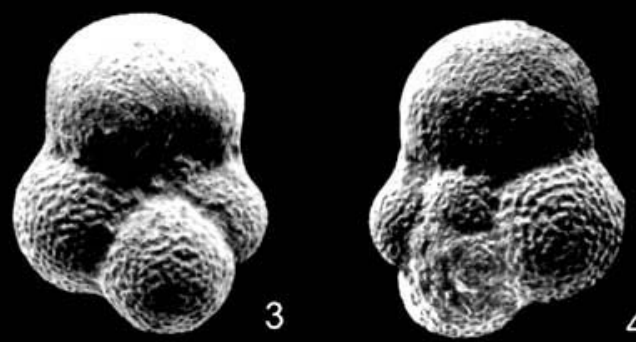

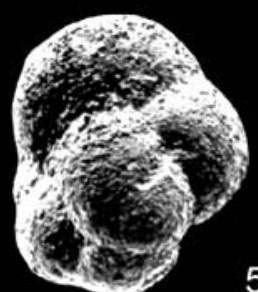

5

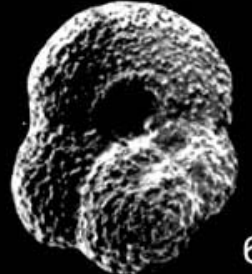

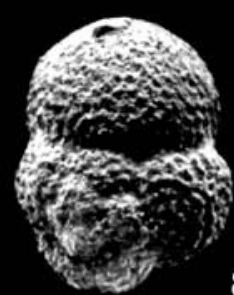

8

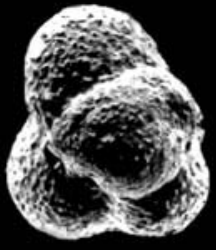

9

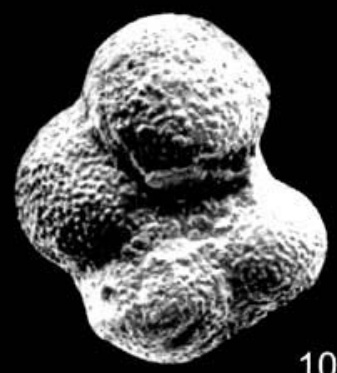

10

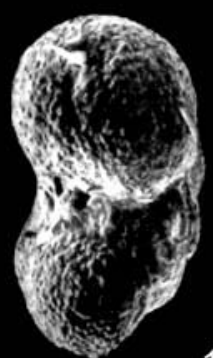

11
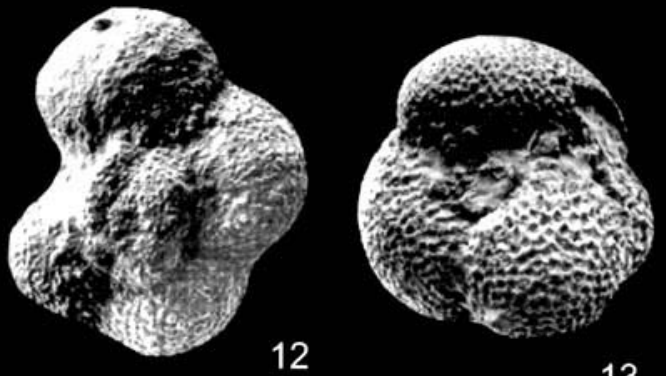

12
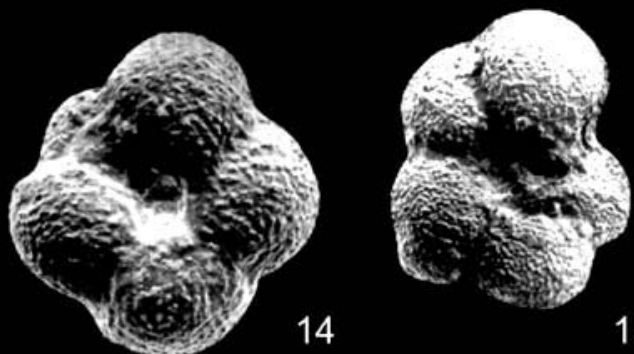

15

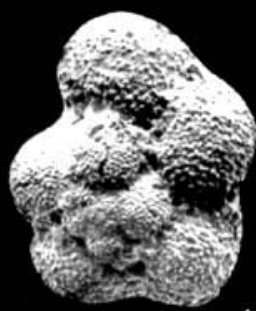

16
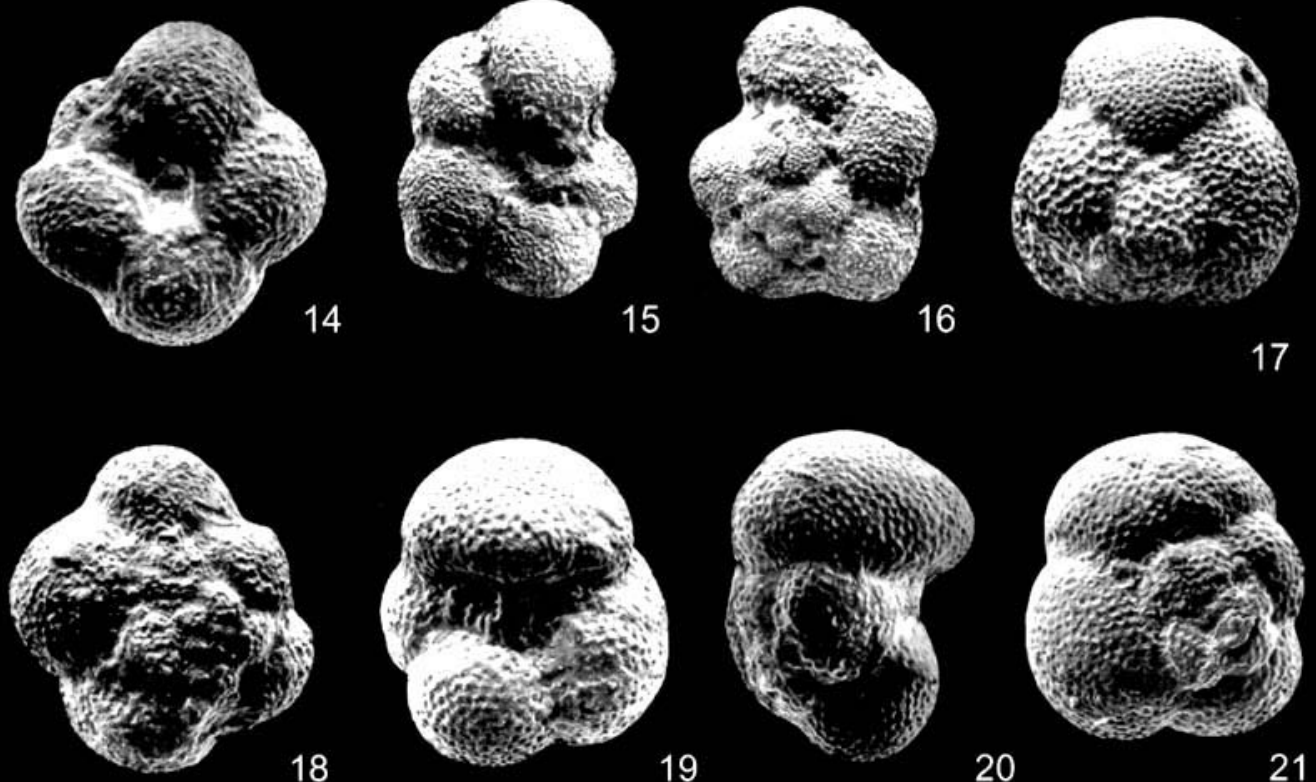

20 
taxa of some biostratigraphic significance, such as Globigerina anguliofficinalis-angulisuturalis group, G. ciperoensis (Plate 5, figs 14 and 18), G. euapertura (Plate 5, figs 19-21), $G$. ouachitaensis, G. ouachitaensis gnaucki (Plate 5, figs 10-12) and Paragloborotalia opima opima, which support an Early Oligocene age assignment (Zones P19-P21 as defined by Berggren \& Miller, 1988). As no biserial planktonic foraminifera (chiloguembelinids) have been recorded, we lack the estabilished criterion to separate the Early from the Late Oligocene (= extinction of chiloguembelinids, Berggren \& Miller, 1988; Berggren et al., 1995). However, the recovery of Nummulites without lepidocyclinids in the entire Shahat Marl interval at well A 1-36 strongly suggests an Early Oligocene age. Small benthic foraminiferal species are also numerous and typical Oligocene elements include Textularia schencki (Plate 4, fig. 3), Uvigerina jacksonensis, Cibicidoides mexicanus (Plate 4, figs 15-17), Asterigerina bartoniana, Bolivina beyrichi and Cibicidina antiqua. In well A1-36 the lower and middle beds of the Shahat Marl Member show a sharp change in their larger foraminiferal content from the underlying unit. Together with Operculina spp. and other nummulitids, the Early Oligocene is marked by the recovery of reticulate Nummulites including $N$. cf. fichteli and $N$. cf. vascus. In the CA section the biotic components in the middle and upper parts of the Oligocene succession are heavily controlled by facies constraints which make the foraminiferal record discontinuous. However, at least the top Al Abraq and the Al Faidiyah Formations can be assigned to the Late Oligocene by means of their total foraminiferal content. Planktonics include some of the above-mentioned taxa and others, such as Catapsydrax dissimilis (Plate 5, fig. 9), Paragloborotalia opima nana, $P$. pseudocontinuosa and $P$. siakensis (Plate 5, figs 15 and 16), which suggest a fairly wide age determination (Zones P19 to P22 of Berggren \& Miller, 1988). A useful chronological constraint is probably the disappearance of Nummulites spp. recorded in the Upper part of the Al Abraq Formation of the CA section. As other nummulitids (Operculina) and ecologically consistent taxa are present up to the top of the section, we assign a biostratigraphic significance to this disappearance. In terms of the Letter zonation of Adams (1970), both Oligocene successions can be included in the zones Tc and Td (Fig. 2). In well A1-36 the boundary with the overlying Miocene beds is marked by a major unconformity.

\section{Miocene}

Rocks ascribed to the Miocene are limited to the Al Faidiyah Formation of the A1-36 well. The base of this interval is recognized through a sharp facies change corresponding to the Miocene transgression. Age-diagnostic larger and small benthic foraminifera are abundant, whereas planktonic taxa have only an occasional record. Significant larger foraminiferal cooccurrences include those of Borelis melo (Plate 3, figs 4 and 6), Lepidocyclina (Eulepidina) cf. dilatata, Miogypsina sp. 1 (Plate 3, fig. 7), Operculina complanata and Spiroclypeus spp. With the exception of $B$. melo, this assemblage may only indicate a broad Oligo-Miocene time interval. The species of Borelis known to date fall into two main groups defined through a length/diameter index (Hottinger, 1974; Sherif, 1991): a group of ovoid to fusiform species (Oligocene to Recent), and a group of spherical forms (Middle-Late Eocene to Recent). Well known from Lower to Middle Miocene strata (Hottinger, 1974), B. melo has only a spherical morphology in the Mediterranean region (Adams, 1984). In well A $1-36 \mathrm{~B}$. melo is relatively common either in thin section or as isolated specimens. This taxon has been recognized in Libya in the same time interval by Berggren (1967) and more recently by Sherif (1991) from the middle Miocene Al Khums Formation (northwest Libya). Supportive biostratigraphic evidence arises from sporadic occurrences of Praeorbulina glomerosa (Plate 5, figs 1 and 2) in the upper beds of the Al Faidiyah Formation. This recovery allows documentation of the planktonic foraminiferal Zone M5b (lower Middle Miocene) of Berggren et al. (1995). The Miocene Al Faidiyah Formation can be ascribed to the Letter Zones $\mathrm{Te}_{5}$ and $\mathrm{Tf}_{1}$ of Adams (1984).

\section{PALAEOENVIRONMENTAL DISTRIBUTION OF FORA- MINIFERA}

Figure 5 presents a sketch of the environmental distribution of the most significant taxa recovered in the studied successions. The range of each taxon is compounded to include both environmental and stratigraphic relationships. The standard carbonate facies belts (SMF) of Wilson $(1974,1975)$, integrated with the foraminiferal distribution model of Hallock \& Glenn (1986), have been used as reference categories.

\section{Larger Foraminifera}

Nummulitids are generally abundant and two basic groups of Nummulites have been recognized through their size and overall morphology, regardless of the proportions between megalospheric and microspheric generations, for which a 15:1 ratio (A versus $B$ forms) has been averaged. Large $(1-5 \mathrm{~cm})$ and flat Nummulites (e.g. $N$. gizehensis) have been recovered from the Middle Eocene microfacies A and B; these have been attributed to a shelf margin-foreslope setting (Wilson's SMF 3 to SMF 4). Patterns of distribution of the larger foraminifera in microfacies $A$ and $\mathbf{B}$ do not indicate any accumulation comparable with the 'Nummulites banks' or 'Nummulites reefs' reported by Arni (1965) from the Sirte Basin or from elsewhere in the Mediterranean region (e.g. Decrouez \& Lanterno, 1979; SerraKiel \& Reguant, 1984). Rather, the composition and distribution of the Eocene Nummulites-dominated assemblages of northern Cyrenaica can be compared with those proposed by Luterbacher (1984) for the southern Pyrenees. In most of the Dernah Formation, the density and diversity of the Nummulites assemblages are largely uniform, and nummulitid shells are consistently recovered from microfacies with abundant biodetrital constituents displaced from shallower settings. In the CA section El Hawat \& Shelmani (1993) described coarseningupwards sequences developing large-scale, sigmoidal bodies which have been assigned to a nummulitic bank complex. With the exception of microfacies A, which comprises a small interval of lime mudstone with displaced, fragmented nummulitid shells, the wackestone and packstone we observed from the Dernah Formation have a dominance of large, flat nummulitid shells arranged parallel to bedding (Plate 1, fig. 5). This indicates some hydrodynamic control on the biotic composition, although the depositional texture is mostly composed of lime mudstone. From the Late Eocene and above, small-sized $(<1 \mathrm{~cm})$, thick, 
Foraminiferal distribution of Eocene-Miocene, NE Libya

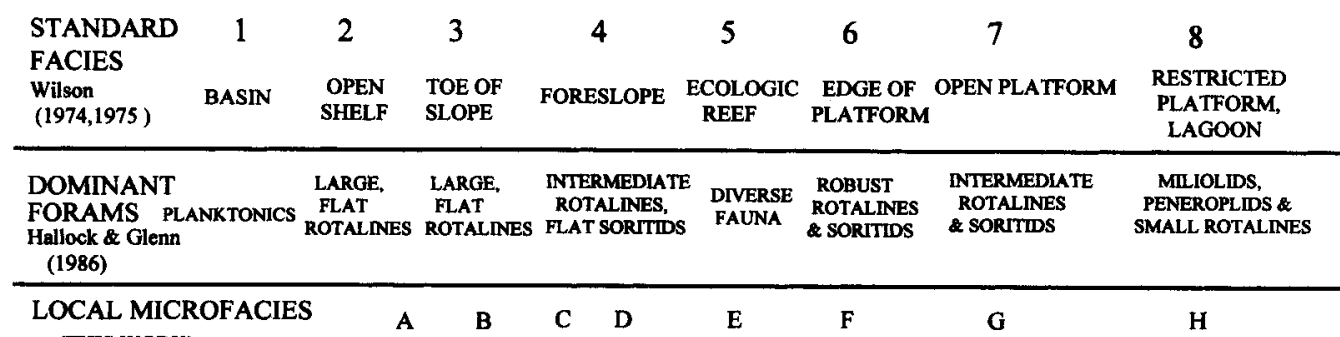

$\begin{array}{lcccccccc}\begin{array}{c}\text { (THIS WORK) } \\ \text { UNITS }\end{array} & \text { A } & \text { B } & \text { C } & \text { D } & \text { E } & \text { F } & \text { G } & \text { H } \\ \text { Depth } & \text { DERNAH FM. } & & \text { AL BAYDA FM. } & \text { AL ABRAQ FM. } & \text { AL FAIDIYAH FM. }\end{array}$
Depth $m$ Shahat Marl Algal Limestone

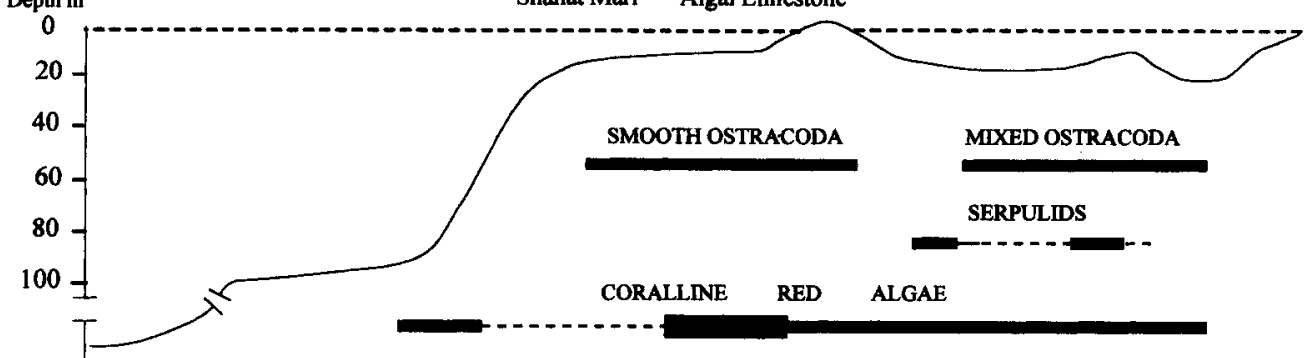

LARGER FORAMINIFERA

Nummilitids

Large flat Nummulites

Small thick Nummulites

Large Operculina

Small Operculina

Small Discocyclina

Sphaerogypsina spp.

Spiroclypeus spp.

Miogypsina spp.

Amphistegina spp.

Borelis melo.

Lepidocyclina (Eulepidina)
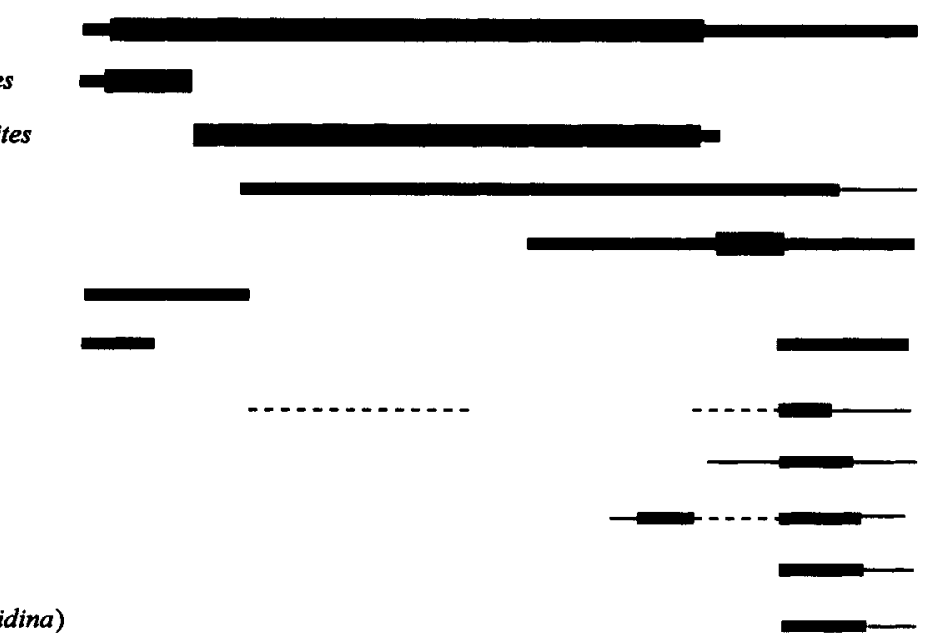

\section{SMALLER FORAMINIFERA}

Planktonic Foraminifera

Miliolids

Cibicidoidids

Nonionids

Rotaliids

Uvigerinids/Textulariids

Ammoniids

Elphidiids

Lenticulinids

Eponidids

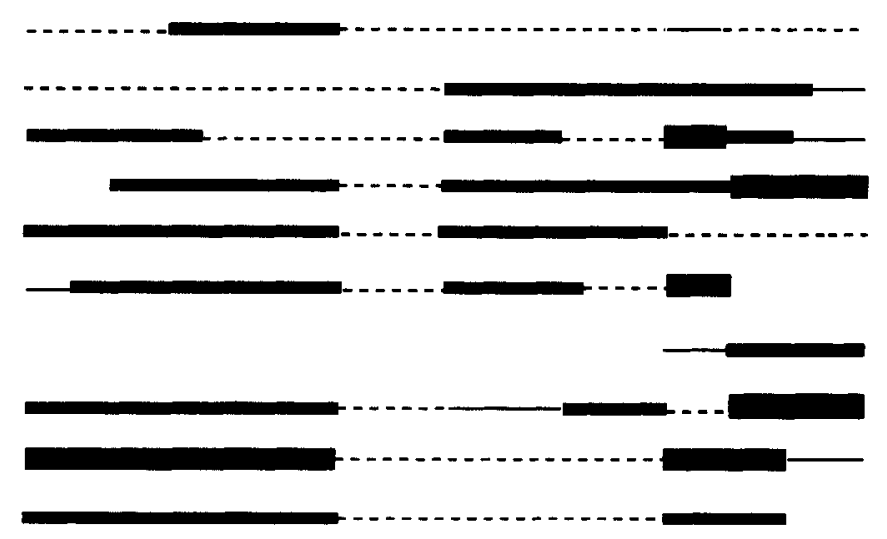

Fig. 5. Environmental distribution of the most significant taxa in the Dernah, Al Bayda, Al Abraq and Al Faidiyah Formations. 
reticulate and/or striate Nummulites ( $N$. cf. fabianii in the Late Eocene, $N$. cf. fichteli and $N$. cf. vascus in the Oligocene) are abundant through microfacies $B$ to sub-microfacies $G_{2}$. These assemblages have a wide distribution from foreslope (SMF 4) to open platform settings (SMF 7). Large-sized Operculina (>1 cm, given as Operculina spp. in the range charts) are common in most of the Oligo-Miocene deposits (microfacies $\mathrm{C}$ to $\mathrm{H}$ ) and include the foreslope (SMF 4) up to the restricted platform settings (SMF 8). Small-sized Operculina $(<1 \mathrm{~cm}$, including Operculina complanata) are common from the edge of the platform (SMF 6) to the restricted platform (SMF 8). Operculinas show conspicuous shell accumulations, parallel to bedding, in the uppermost part of the sub-microfacies $\mathrm{G}_{2}$, and, at the outcrop scale (top of the Al Abraq Formation), they form a characteristic Operculina bed. Other larger foraminifera, such as Spiroclypeus, Miogypsina, Amphistegina, Lepidocyclina (Eulepidina) and Borelis melo, typify microfacies $\mathrm{H}$ and are common from open to restricted platform (SMF 7 and 8).

\section{Small Foraminifera}

Small benthic foraminifera are present in most of the platform sedimentary belts, with the exception of the ecological reef belt (SMF 5), where they are scarce, limited to attached taxa and associated with coralline red algae, nummulitids and biodetritus produced by reef-associated biota. Miliolids are common throughout the open and restricted platform (SMF 6 to 8), whereas they are rare in open shelf settings. In Miocene deposits, nonionids, ammoniids and elphidiids are abundant and typify open to restricted platform palaeohabitats (SMF 7 and 8), whereas they are less common or absent in other parts of the platform belt. Cibicidoidids, uvigerinids and agglutinated taxa exhibit a patchy distribution both in shelf and open platform settings. The abundance of typically open shelf taxa, such as coiled vaginulinids, eponidids and uvigerinids, in open to restricted platform belts may be in part related to storm-induced transport. Planktonic foraminiferal abundance and diversity are usually low, with the significant exception of the Oligocene foreslope deposits of the Shahat Marl (SMF 4), in which a suitable (marly) lithofacies may explain their abundant record.

\section{BIOTIC ECOLOGY VERSUS PALAEOCOLOGY}

The spatial and temporal distribution of a given palaeohabitat can be better interpreted by comparison with its present day counterpart. In the following section we examine the fossil assemblages in light of the known ecological information and with the assumption that patterns of fossil abundance and distribution are similar to those found for living assemblages (Dodd \& Stanton, 1990). The great variety of microfacies and fossil assemblages recognized in this study reflects (1) the variety of environmental settings and (2) the effect of the lithofacies on fossil recovery.

In general, larger and small foraminifera from the midCenozoic of northern Cyrenaica are a mix of infaunal and epifaunal taxa in which we recorded a prevalence of free, larger epifaunal types. Studies on present day tropical-subtropical, euphotic environments indicate that the nature of the substrate, water energy and light determine the structure and abundance of the biotic communities (Hottinger, 1983, 1989; Reiss \& Hottinger, 1984; Hallock \& Glenn, 1986; Goldring, 1995; Travé et al., 1996) and, to a certain extent, they influence other primary environmental factors. Pertinent examples are from the Gulf of Aqaba (Hottinger, 1977, 1983), where on soft substrates (low energy conditions) the permanent vegetation colonizing the seafloor allows the vegetation-derived organic matter to be recycled by the burrowing communities. In contrast, on hard substrates (high energy conditions), in which sessile communities show a prevalence of long-living stony corals, many organisms, including foraminifera, have algal symbionts for nutrient recycling. Larger foraminifera possess symbionts, such as zooxanthellae and diatoms (Lee, 1980), and, being involved in the foraminiferal metabolism, they have specific relationships with any given taxon (Leutenegger, 1984). Considering the direct relationship between the light spectrum and type of symbionts, the depth distribution of the larger foraminifera seems to be largely determined by their symbionts (Leutenegger, 1983, 1984) and, therefore, their depth range is limited to the euphotic zone (Hottinger, 1983). As suggested by Haynes (1965), however, the shape of larger foraminifera is probably a compromise between environmental hydrodynamics and the metabolic requirements of algal symbiosis.

Morphological changes with changing depth have been described in different larger foraminiferal groups and these involve their overall morphology and the development of internal structures to strengthen the test. For example, a trend towards flattening with and increase in depth seems to be a morpho-functional adaptation to a symbiont-bearing strategy. Changes in the wall surface to volume ratio, leading to a more flattened shape, enable more symbionts to be hosted and this has been described for nummulitids and amphisteginids (Hallock \& Glenn, 1986). Palaeoecologically, these results may suggest that assemblages dominated by large and flat nummulitids characterize deep environments, compared to the carbonates of marginal marine settings. Similarly, the addition of internal structures (e.g. the secondary septa in Heterostegina) may help the test to be more robust and, consequently, allow thinner walls. This may operate in a similar manner to a glasshouse (Haynes, 1965). Because of their symbiotic relationships, larger foraminifera are well adapted to oligotrophic conditions (Hallock, 1988) and, moreover, it has long been recognized that they typify warm water habitats (Murray, 1973).

Salinity is considered to be a significant foraminiferal limiting factor (Murray, 1991). Rotaliine larger foraminifera are typically stenohaline, with tolerance limits of the order of 30 40\% (Reiss \& Hottinger, 1984; Hallock \& Glenn, 1986). Shallow-water miliolines, however, are common in lagoons and similar environments and are capable of tolerating higher salinities than rotaliines (Murray, 1991). However, the abundance of miliolines in itself in a given fossil assemblage should not necessarily be interpreted as indicative of hypersaline conditions.

Ecological studies of the microhabitats of present day small benthic foraminifera may be used for reconstructing ancient environments. This is because microhabitat preferences seem to be independent of taxonomy, being related to distinct morphological groups (Corliss, 1985, 1991). The relative proportions between taxa with either an epi- or infaunal mode of life in a fossil assemblage can provide information on the nature of the substrate, chemico-physical characteristics, oxygen and nutrient 
levels (Gooday, 1994). Although most of the published work on foraminiferal microhabitats is devoted to deep-sea taxa, pertinent accounts on shallow-water taxa include those by Langer et al. (1989) and Kitazato (1994), whose synecological studies on Ammonia may be applied to Rotalia - a Palaeogene quasi-homeomorph of the living Ammonia--which is an abundant faunal element in the middle Cenozoic of northern Cyrenaica.

Apart from foraminifera, coralline algae are significant biotic components of the rocks studied and coralline algal frameworks abound in most of the coral-algal unit of the Al Bayda Formation. Studies of living reef-associated environments indicate that the taxonomic composition, shape, diversity and density of coralline algae are related to a number of factors, such as the light intensity, the quality of the substrate, the hydrodynamics and the relationships with other biotic components (Cloud, 1975; Wray, 1977; Adey, 1979; Perrin et al., 1995); their observed interplay makes the use of corallines alone as a palaeoecological tool difficult. With reference to the shape, which has the potential advantage of being taxonomically independent, encrusting forms seem to typify solid substrates and turbulent shallow environments (Johnson, 1961; Wilson, 1975; Wray, 1977); however, similar morphologies have been found from 30 to $80 \mathrm{~m}$ depth in the Indo-Pacific and Caribbean (Adey, 1979) and between 30 and $110 \mathrm{~m}$ depth in the Mediterranean (Bosence, 1985). Branching and nodular forms, which are common coralline morphologies in the upper $\mathrm{Al}$ Bayda Formation, are reported from less than $30 \mathrm{~m}$ depth, but they are also abundant between 30 and $90 \mathrm{~m}$ (Cloud, 1975). In their coralline algal zonation, Perrin et al. (1995) state that branching forms are generally found in shallow water, down to $10-15 \mathrm{~m}$, whereas domal, massive or columnar colonies are dominant in deeper water. However, if light is the major factor controlling the distribution of coralline communities (Perrin et al., 1995), these should be used with caution as palaeobathymetric indicators, as the relationship between light intensity and depth variation may be controlled by factors of independent bathymetry.

\section{PALAEOENVIRONMENTAL CONDITIONS AND TRENDS}

Since the eustatic sea-level curve of Vail et al. (1977), the recognition of global sea-level changes has allowed a better undertanding of their effects on shelf-living biota, including foraminifera. Pertinent examples from the Cenozoic are numerous and include those by Olsson \& Wise (1987), Seiglie (1987) and Dobson et al. (1991).

In northern Cyrenaica, the late Early Eocene disappearance of deep-water benthic foraminifera (Barr \& Berggren, 1980) should be related to the major sea-level lowstand culminating at the Early-Middle Eocene boundary (Haq et al., 1987). The presence of an important unconformity at this stratigraphic level is documented both in northern Cyrenaica (El Hawat \& Shelmani, 1993) and in the northwestern Libyan offshore (Barbieri, 1990). The Cenozoic palaeobathymetric history of Al Jabal al Akhdar, however, reflects the prevailing effect of locally active tectonics over large-scale bathymetric changes. Röhlich $(1978,1980)$, in a series of Late Cretaceous to Late Oligocene palaeogeographical maps of northern Cyrenaica, has shown how diastrophic movements produced NE-SW oriented emergent areas that were responsible for the main stratigraphic gaps and strongly influenced the sediment accumulation rates.

\section{Dernah Formation}

The biofacies distribution in the Dernah Formation reflects its abrupt lithological changes (e.g. carbonate versus dolomitic levels) and this is a serious limitation for a palaeobathymetric reconstruction. However, in well A1-36 the marly interbeds of this mostly carbonate succession yielded sufficiently well preserved small benthic foraminifera. These assemblages are characterized by large-sized specimens of epifaunal and shallow infaunal genera such as Rotalia ( $R$. mexicana), Elphidium (mostly E. glabratum) and Lenticulina (mostly L. texana), which are common components of shallow shelf environments with a soft and/or vegetative substrate.

The increase in size and number of Nummulites, which has been observed up sequence may reflect either hydrodynamic control or improved habitat conditions. The abundance of Nummulites, associated with branching, articulated and/or encrusting red algae, and other less frequent larger foraminifera, such as small Discocyclina, Operculina and Sphaerogypsina, characterizes most of the Dernah Formation (microfacies B). A similar assemblage has been considered characteristic of a lowenergy, carbonate shelf environment with a bathymetric range between 10 and $40 \mathrm{~m}$ (Berggren, 1974; Hottinger, 1983).

\section{Al Bayda Formation}

As previously stated, a disconformity marks the contact between the Eocene succession and the overlying Lower Oligocene Al Bayda Formation. In well A1-36 the marly lithology of this unit allowed the separation of a foraminiferal assemblage, whereas the outcrop section was mainly investigated by means of microfacies because of the prevailing marly carbonate lithology. The Al Bayda Formation outlines a generalized shallowing-up evolution. However, the changing biotic contents observed upsequence allows us to trace palaeobathymetric oscillations that are probably related to the structurally dynamic region (Röhlich, 1978) in which changes of palaeodepth in an open shelf environment of deposition is documented by the largescale, cyclic alternation of the microfacies $C$ (nummulitid packstone) and $\mathrm{D}$ (planktonic foraminiferal mudstone-wackestone) in the Shahat Marl Member of the CA section. Palaeodepth-diagnostic small benthic foraminifera recovered from the Shahat Marl of well A1-36 include Uvigerina jacksonensis, a typical carbonate shelf uvigerinid (Boersma, 1984) and Cibicidoides mexicanus. For the latter taxon, a morphological cline from middle neritic to bathyal settings has been described (van Morkhoven et al., 1986) by relating the increase in the degree of convexity of the dorsal side to the increase in palaeodepth. This was proved to be of a more general significance by similar morphological trends observed in other phylogenetically unrelated taxa (Barbieri, 1991). Further evidence of a shallow shelf environment of deposition derives from the planktonic foraminiferal assemblages, which are abundant, but only composed of surface (Globigerina ciperoensis, $G$. ouachitaensis, Tenuitellinata angustiumbilicata) and intermediate (G. praebulloides) dwellers (depth ranking after Keller et al., 1992). 
The proximity of a steep platform foreslope is documented through the abundance of locally derived biogenic debris, including fragments of Discocyclina reworked from the underlying Eocene deposits (CA section). As biodetritus (particularly nummulitid and discocyclinid fragments) is mostly recovered in microfacies $C$, we assume that changes in water palaeodepth, rather than the steepness of the platform edge, mainly controlled such biodetrital input.

The upper unit of the Al Bayda Formation (Algal Limestone Member) establishes a dramatic change in the environment of deposition. At the outcrop scale, a build-up produced by in situ coral colonies (ecological reef sensu Dunham, 1970, equivalent to Wilson's SMF 5) and coral blocks eroded seawards from the reef make up the lower part of the Algal Limestone Member in the CA section. This is included in microfacies $\mathrm{E}$, in which, however, coralline (melobesioid) algae are the main biogenic component. At the microfacies scale, sediments appear to be largely encrusted and the coral-algal framework is frequently infilled by mud and sand. Microfacies $E$ is interpreted to have been deposited in the shallow forereef of an organic reef complex, a composite physiographic element that may develop from the surf zone down to $40-50 \mathrm{~m}$ water depth or more (Wilson, 1975; Reijers \& Hsü, 1986; Perrin et al., 1995). Together with coralline algae, such as Mesophyllum and Lithothamnion, commonly occurring biotic elements of microfacies $\mathrm{E}$ include small-sized and thick larger foraminifera, attached (Cibicidina antiqua and Lobatula lobatula) and free small benthic foraminifera (Rotalia mexicana, miliolids and textulariids). The predominance of mud/sand dwellers over attached forms in the foraminiferal assemblages of microfacies $\mathrm{E}$ may be explained through displacements down to the platform margin of shallower materials, as observed elsewhere (e.g. Reid \& Macintyre, 1988), and this may ultimately have had a significantly negative effect on the coral cover by increasing the water turbidity.

The upper part of the Algal Limestone Member is made up of microfacies F and is interpreted to be deposited in Wilson's SMF 6 to 7 (shoal of platform edge to open platform). In microfacies $F$ nummulitids are abundant, whereas coralline red algae are scarce and locally absent. The re-appearance of Nummulites, together with the abundance of other soft-substrate dwellers (mainly Rotalia mexicana) and epiphytes (bolivinids, miliolids, Asterigerina bartoniana, Lobatula lobatula), indicates substantial changes in the nature of the substrate. Although micrite is still common, the biotic composition and the poor sorting of the skeletal grains and intraclasts indicate considerable changes in energy conditions, well below sea level. Similar fossil assemblages have been described by Setiawan (1983) from Late Eocene shoals of northern Italy.

\section{Al Abraq Formation}

The transition between the Al Bayda Formation and the overlying $\mathrm{Al}$ Abraq Formation is marked in the CA section by a sharp palaeoenvironmental change. At the base of the $\mathrm{Al}$ Abraq Formation, a marly limestone interval a few metres thick yielded fairly diverse foraminiferal assemblages including a significant planktonic foraminiferal component. Lithologically, and in terms of microfacies, this short interval is similar to those described for the Shahat Marl Member as microfacies D and contains a typically shallow shelf foraminiferal assemblage. Rotalia mexicana, elphidiids, nonionids, miliolids and asterigerinids, indicating open circulation and muddy substrates, are the prevailing components. Planktonic foraminiferal surface and intermediate dwellers are aiso present.

Most of the Al Abraq Formation exhibits biotic elements broadly indicative of shallow, open shelf settings. The distribution chart presented in Fig. 3 shows the obvious relationship in the CA section between lithofacies and microfossil recovery. There is no evidence of coral communities but, however, reefoid limestones characterize the middle part of the $\mathrm{Al}$ Abraq Formation in the Wadi Derna section (Zert, 1974), about $30 \mathrm{~km}$ north the location of well A1-36. The analysis of microfacies and free foraminiferal assemblages indicate some degree of biotic mixture throughout the unit. The subdivision into two sub-microfacies, $G_{1}$ and $G_{2}$, is mainly related to lithological evidence, sub-microfacies $G_{2}$ being typified by siliclastic materials and abundant glauconite pellets that, at the outcrop scale, produce an appearance of dark spots. Both submicrofacies are characterized by skeletal wackestone and packstone in which displaced reef-associated (from back- to fore-reef) communities, including bryozoans, crustose coralline algae, serpulids, bivalves and gastropods, make up most of the biodetritus. Their provenance from a nearby reefoid complex is suggested by the recovery of thick-shelled, small Nummulites, thick-shelled Amphistegina and small miliolid-dominated microfacies of presumable lagoonal origin. The remaining small foraminiferal assemblage is assumed to be in situ and is characteristic of a shallow shelf with a vegetated, soft substrate. This free-living community includes both epiphytes and sediment-dwelling species. Accordingly, autochthonous larger foraminiferal assemblages have a prevalence of soft substrate dwellers (e.g. Operculina and Nummulites) over hard substrate dwellers (e.g. Heterostegina).

A shallowing-upwards trend in the Al Abraq Formation is suggested by the siliciclastic component (sub-microfacies $G_{2}$ ) in the upper half of the unit, which may be produced by continentally derived sediment input attributable to a sea-level lowering. Further evidence derives from the abundant assemblage of Operculina complanata with prevalent small and thick specimens, relative to the species. Morphological trends on Operculina, showing thicker tests at shallower depths, have been reported by Fermont (1977) from the Gulf of Aqaba and, following the discussion in a previous section, such trends in the overall morphology of larger symbiont-bearing foraminifera probably have a wider validity, being described from phylogenetically unrelated taxa.

\section{Al Faidiyah Formation}

The Al Faidiyah Formation is present in the two study successions. However, whereas in the CA section the marly, Late Oligocene part of the formation conformably overlies the $\mathrm{Al}$ Abraq Formation, a major unconformity marks the $\mathrm{Al}$ Bayda (Early Oligocene)-Al Faidiyah (Early Miocene) transition in the well A1-36. On the whole, the two sections provide a sufficiently exhaustive palaeoenvironmental account of this lithostratigraphic unit and, apart from a strongly dolomitized interval near the base of the unit in well A1-36, the two successions provided accurate microfaunal lists. 
At the base of the unit in the CA section, changes in the biotic component with respect to the underlying rock unit indicate a significant increase in palaeodepth. Assemblages suggesting outer shelf conditions are diverse and include anomalinids, cibicidoids, gavelinellids, planulinids, sphaeroidinids and planktonic foraminifera, although inner neritic taxa do exist. The marly carbonate microfacies described from this interval correspond to those previously described for the microfacies D. By comparison, the Miocene section of the Al Faidiyah Formation (well A1-36) contains foraminiferal assemblages of lagoon-inner neritic settings, including Borelis, Miogypsina, Asterigerinata, cibicidids, miliolids and elphidiids, which abound throughout the interval and make up the biotic bulk of microfacies $H$. The assignment of this microfacies to Wilson's SMF 8 (restricted platform and lagoon) also applies to the depositional texture of the rock, consisting of pelleted, diagenetically altered packstone and grainstone. Interestingly, abundant operculinid assemblages, which are assumed to thrive in open shelf settings down to a few tens of metres water depth (Hottinger, 1983), are limited to the lower part of the interval and this suggests an up-sequence trend towards more restricted conditions.

Some taxonomic mixtures reflect the use of ditch cuttings samples, and the consequent contamination by caving, in studying this Miocene interval. Examples include the recovery in the same stratigraphic levels of shallow-water taxa with different ecological requirements in terms of salinity (e.g. the hypersaline Borelis and the normal marine Miogypsina), substrate conditions and distribution on the continental shelf (e.g. the lagoonal Borelis and the open shelf Miogypsina and Operculina).

\section{CONCLUSIONS}

The nine different microfacies and sub-microfacies described from the middle Cenozoic succession of Al Jabal al Akhdar belong to a shelf-carbonate platform complex. Their stratigraphic distribution indicates a generalized shallowing-upwards trend and the depositional environments, from open to progressively more restricted conditions, include the open shelf (microfacies $\mathrm{A}$ and $\mathrm{B}$ ), platform foreslope (microfacies $\mathrm{C}$ and D), forereef (microfacies E), shoal of platform edge (microfacies F), backreef to open platform (microfacies $G$ ) and restricted platform (microfacies $\mathrm{H}$ ). The biotic contents of microfacies, complemented by the matrix-free microfaunal assemblages, allow us to properly define the different lithostratigraphic units in terms of palaeoecology and palaeobathymetry. The taxonomic composition of the foraminifera show high diversities, at the generic and specific levels, and some taxonomic mixing. This suggests that in transitional conditions diversification may be significantly higher than in each single environmental setting.

Palaeobiogeographically, the Palaeogene foraminiferal assemblages of Al Jabal al Akhdar have some degree of similarity with assemblages from the Caribbean and Indo-Pacific. Large-scale taxonomic comparisons, however, show limitations related to local lithofacies constraints.

The limited number of age-diagnostic foraminifera recognized does not allow the systematic application of a detailed biozonation. Nevertheless, the four units that comprise the study succession contain age-related taxa indicating the Middle to Late Eocene (Dernah Formation), the Early Oligocene (Al Bayda Formation), the Early to Late Oligocene (Al Abraq Formation) and the Late Oligocene to Middle Miocene (Al Faidiyah Formation).

\section{ACKNOWLEDGMENTS}

This research was supported by the Earth Science Department of Garyounis University, Benghazi, as part of E. Abdulsamad's PhD dissertation, and by MURST to $R$. Barbieri. We are grateful to the staff of the Geological Laboratory of the Arabian Gulf Oil Company, especially A. Mufftah, F. Bu-Argoub, A. ElMehaghag and S. Al-Garyani, who made available the subsurface samples, some geological data and who helped during field work. S. Atia, M. Moktar, R. Gamberini and L. Ferracuti processed part of the samples, P. Ferraresi drafted the figures and $\mathbf{P}$. Ferrieri assisted with SEM preparation and printed the photomicrographs. Thanks are also due to J. Pignatti for discussion on some larger foraminiferal taxonomy and for a critical reading of the manuscript, and to G. A. Pini for improving the quality of the plates.

\section{Manuscript received November 1997 Manuscript accepted March 1999}

\section{REFERENCES}

Adams, C. G. 1967. Tertiary foraminifera in the Tethyan, American and Indo-Pacific provinces. In Adams, C. G. \& Ager, D. V. (Eds), Aspects of Tethyan Biogeography. Systematics Association, Publication, London, 7: 195-217.

Adams, C. G. 1970. A reconsideration of the East Indian letter classification of the Tertiary. Bulletins of the British Museum (Natural History), Geology, 19: 85-137.

Adams, C. G. 1984. Neogene larger foraminifera, evolutionary and geological events in the context of datum planes. In Ikebe, N. \& Tsuchi, R. (Eds), Pacific Neogene Datum Planes. University of Tokyo Press, Tokyo, 44-67.

Adams, C. G., Gentry, A. W. \& Whybrow, P. J. 1983. Dating the terminal Tethyan event. Utrecht Micropaleontological Bulletins, 30: 273-297.

Adey, W. H. 1979. Crustose coralline algae as microenvironmental indicators in the Tertiary. In Gray, J. \& Boucot, A. J. (Eds), Historical Biogeography, Plate Tectonics and Changing Environment. Oregon State University Press, Corvallis: 459-464.

Arni, P. 1965. L'evolution des Nummulitinae en tant que facteur de modification des dépots littoraux. Mémoires du Bureau de Recherches Géologiques et Minières, 32: 7-20.

Banerjee, S. 1980. Stratigraphic Lexicon of Libya. Department of Geological Researches \& Mining, Bulletin No., 13, Industrial Research Center, Tripoli.

Barbieri, R. 1990. L'Eocene medio e superiore del bacino di Tripolitania (Libia nord occidentale): biostratigrafia e paleoecologia. Bollettino della Societá Paleontologica Italiana, 29: 253-271

Barbieri, R. 1991. Phenotypic variation in Gyroidinoides altiformis (Stewart \& Stewart) and Gyroidinoides subangulatus (Plummer) (Foraminifera). Journal of Micropalaeontology, 9: 239-244.

Barr, F. T. (Ed.) 1968a. Geology and Archaeology of Northern Cyrenaica, Libya. The Petroleum Exploration Society of Libya, Tripoli.

Barr, F. T. 1968b. Upper Cretaceous stratigraphy of the Jabal al Akhdar, Northern Cyrenaica. In Barr, F.T. (Ed.), Geology and Archaeology of Northern Cyrenaica, Libya. The Petroleum Exploration Society of Libya, Tripoli: 131-147.

Barr, F. T. 1972. Cretaceous biostratigraphy and planktonic foraminifera of Libya. Micropaleontology, 18: 1-46.

Barr, F. T. \& Berggren, W. A. 1980. Lower Tertiary biostratigraphy and tectonics of northern Libya. In Salem, M. J. \& Busrewil, M. T. (Eds), Geology of Libya. Vol. I. Academic Press, London: 162-192. 
Barr, F. T. \& Hammuda, O. S. 1971. Biostratigraphy and planktonic zonation of the Upper Cretaceous Atrun Limestone and Hilal Shale, Northeastern Libya. In Farinacci, A. (Ed.), Proceedings of the Second International Conference on Planktonic Microfossils. Vol. I. Tecnoscienza, Rome: $27-40$.

Barr, F. T. \& Weegar, A. A. 1972. Stratigraphic Nomenclature of the Sirte Basin, Libya. The Petroleum Exploration Society of Libya, Tripoli.

Batjes, D. A. Jr 1958. Foraminifera of the Oligocene of Belgium. Mémoires Institut Royal des Sciences Naturelles de Belgique, 143: 131173

Benjamini, Ch. 1995. Planktonic foraminifera distribution and zonal stratigraphy. In Schaub, H., Benjamini, Ch. \& Moshkovitz, S. (Eds), The Biostratigraphy of the Eocene of Israel. Mémoires Suisses de Paléontologie, 117: 1-55.

Berggren, W. A. 1967. Biostratigraphy and planktonic foraminiferal zonation of the Tertiary System of the Sirte basin of Libya, North Africa. In Brönnimann, P. \& Renz, H. H. (Eds), Proceedings of the First International Conference on Planktonic Microfossils. Vol. I. E. J. Brill, Leiden: 104-120.

Berggren, W. A. 1974. Paleocene benthonic foraminiferal biostratigraphy, biogeography and paleoecology of Libya and Mali. Micropaleontology, 20: 449-465.

Berggren, W. A. \& Miller, K. G. 1988. Paleogene tropical planktonic foraminiferal biostratigraphy and magnetobiochronology. Micropaleontology, 34: $362-380$.

Berggren, W. A. \& Phillips, J. D. 1971. Inffuence of continental drift on the distribution of Tertiary benthonic foraminifera in the Caribbean and Mediterranean regions. In Gray, C. (Ed.), Symposium on the Geology of Libya. Imprimerie Catholique, Beriut: 263-299.

Berggren, W. A., Kent, D., Swisher, C. C. \& Aubry, M.-P. 1995. A revised Cenozoic geochronology and chronostratigraphy. In Berggren, W. A. \& Kent, D. (Eds), Geochronology Time Scales and Global Stratigraphic Correlation. SEPM Special Publication No. 54, 134-175.

Blondeau, A. 1972. Les Nummulites. Vuibert, Paris.

Boersma, A. 1984. Handbook of Common Tertiary Uvigerina. Microclimates Press, New York.

Bosence, D. W. J. 1985. Preservation of coralline-algal reef frameworks. In Gabrie, C. \& Harmelin, V. (Eds), Proceedings of 5th International Coral Reef Congress, Tahiti, 6: 623-628.

Bolli, H. M., Beckmann, J-P. \& Saunders, J.B. 1994. Benthic Foraminiferal Biostratigraphy of the South Caribbean Region. Cambridge University Press, Cambridge.

Boukhary, M. \& Hussein-Kamel, Y. 1993. What is Nummulites gizehensis (Forskål) s. str.?. Revue de Micropaléontologie, 36: 3-18.

Chapronière, G. C. H. 1980. Influence of plate tectonics on the distribution of Late Palaeocene to Early Neogene larger foraminiferids in the Australasian region. Palaeogeography, Palaeoclimatolagy, Palaeoecology, 31: 299-317.

Christie, A. M. 1955. Geological Report on Cyrenaica, Libya. American Overseas Oil Company Reports.

Clarke, W.J. \& Blow, W.H. 1969. The inter-relationships of some Late Eocene, Oligocene and Miocene larger foraminifera and planktonic biostratigraphic indices. In Brönnimann, P. \& Renz, H. H. (Eds), Proceedings of the First International Conference on Planktonic Microfossils, Geneva. Vol. II. E. J. Brill, Leiden: 82-97.

Cloud, P. E. Jr 1975. Facies relationships of organic reefs. In Carbonate Rocks III: Organic Reefs. American Association of Petroleum Geologists Bulletin, Print series, 15: 81-105.

Copestake, P. 1993. Application of micropalaeontology to hydrocarbon exploration in the North Sea basin. In Jenkins, D. G. (Ed.), Applied Micropalaeontology, Kluwer Academic, Dordrecht: 93-152.

Corliss, B. H. 1985. Microhabitats of benthic foraminifera within deepsea sediments. Nature, 314: 435-438.

Corliss, B. H. 1991. Morphology and microhabitat preferences of benthic foraminifera from the northwest Atlantic Ocean. Marine Micropaleontology, 17: 195-236.

Decrouez, D. \& Lanterno, E. 1979. Les 'Bancs a Nummulites' de l'Eocene Mesogéen et leurs implications. Archives des Sciences, Genève, 32: 67-94.

Desio, A. 1935. Studi geologici sulla Cirenaica, sul Deserto Libico, sulla Tripolitania e sul Fezzan Orientale. Missione Scientifica della Reale
Accademia d'Italia a Cufra, 1-3.

Desio, A. 1939. Studi morfologici sulla Libia Orientale. Missione Scientifica della Reale Accademia d'Italia a Cufra, 2.

Di Napoli Alliata, E. 1953. Microfaune della parte superiore oligocenica del Monte San Vito e del Rio Mazzapiedi-Castellania (TortonaAlessandria). In Studi stratigrafici e micropaleontologici sull' Appennino Tortonense. Rivista Italiana de Paleontologia e Stratigrafia, 6: 2598.

Dobson, M. R., Haynes, J. R., Bannister, A. D., Levene, D. G., Petrie, H. S. \& Woodbridge, R. A. 1991. Early Tertiary palaeoenvironments and sedimentation in the NE Main Porcupine basin, offshore western Ireland evidence for global change in the Tertiary. Basin Research, 3 : 99-117.

Dodd, J. R. \& Stanton, R. J. 1990. Paleoecology. Concepts and Applications, Wiley, New York.

Dunham, R.J. 1970. Stratigraphic reefs versus ecologic reefs. American Association of Petroleum Geologists Bulletin, 54: 1931-1932.

Duronio, P., Dakshe, A. \& Bellini, E. 1991. Stratigraphy of the offshore Cyrenaica Libya. In Salem, M. J., Hammuda, O. S. \& Eliagoubi, B. A. (Eds), The Geology of Libya. Vol. IV. Elsevier, Amsterdam: 15891620 .

El Hawat, A. S. \& Salem, M. J. 1987. A case study of the stratigraphic subdivision of Ar Rajmah Fm. and its implication on the Miocene of Northern Libya. In Margit, D. (Ed), Proceedings of the 8 th Conference of the Mediterranean Neogene Stratigraphy. Annals of the Institute of Geology Publications Hungary Budapest, LXX: 173-184.

El Hawat, A. S. \& Shelmani M. A. 1993. Short Notes and Guidebook on the Geology of Al Jabal al Akhdar. Cyrenaica, NE Libya. Interprint, Malta.

El Khoudary, R. H. 1976. Contribution to the stratigraphy and micropalaeontology of Jabal Al Akhdar. Upper Eocene planktonic foraminifera from Wadi Bakur, SE Tukrah, NE Libya. Libyan Journal of Science, 6B: 57-79.

El Khoudary, R. H. 1977. Truncorotaloides libyaensis, a new planktonic foraminifer from Al Jabal al Akhdar (Libya). Revista Española de Micropaleontologia, 9: 326-336.

El Khoudary, R. H. 1980. Planktonic foraminifera from the Middle Eocene of the Northern Escarpment of Al Jabal al Akdar, NE Libya In Salem, M. J. \& Busrewil, M. T. (Eds), The Geology of Libya. Vol. I. Academic Press, London: 193-204.

Eliagoubi, B. A. \& Powell, J. D. 1980. Biostratigraphy and palaeoenvironment of Upper Cretaceous foraminifera of North-central and Northwestern Libya. In Salem, M. J. \& Busrewil, M. T. (Eds), Geology of Libya. Vol. I. Academic Press, London: 137-153.

Fermont, W. J. J. 1977. Biometrical investigation of the genus Operculina in recent sediments of the Gulf of Elat, Red Sea. Utrecht Micropaleontological Bulletins, 15: 111-147.

Flügel, E. 1982. Microfacies Analysis of Limestone. Springer-Verlag, Berlin.

Goldring, R. 1995. Organisms and substrate: response and effect. In Bosence, D. W. J. \& Allison, P. A. (Eds), Marine Palaeoenvironmental Analysis from Fossils. Geological Society, London, Special Publication, 83: 151-180.

Gooday, A. J. 1994. The biology of deep sea foraminifera: a review of some advances and their applications in paleoceanography. Palaios, 9: 14-31.

Gregory, J. W. 1911. Contribution to the geology of Cyrenaica. Quarterly Journal of the Geological Society, London, 67: 572-615.

Hallock, P. 1988. Diversification in algal symbiont-bearing foraminifera: a response to oligotrophy? Proceedings of the Third Internationa Symposium on Benthonic Foraminifera. Revue de Paléobiologie, Special Volume: $789-797$.

Hallock, P. \& Glenn, E. C. 1986. Larger foraminifera: a tool for paleoenvironmental analysis of Cenozoic carbonate depositional facies. Palaios, 1: 55-64.

Haq, B. U., Hardenbol, J. \& Vail, P. R. 1987. Chronology of fluctuating sea-levels since the Triassic. Science, 235: 1153-1167.

Haynes, J. 1965. Symbiosis, wall structure and habitat in foraminifera. Contribution from the Cushman Foundation for Foraminiferal Research, 16: $40-43$.

Herb, R. \& Hekel, H. 1973. Biostratigraphy, variability and facies relations of some Upper Eocene nummulites from northern Italy. 
Eclogae Geologicae Helvetiae, 66: 419-445.

Hottinger, L. 1974. Alveolinids, Cretaceous-Tertiary Larger Foraminifera. Esso Production Research-European Laboratories, A. Schudel, Riehen, Basle.

Hottinger, L. 1977. Distribution of larger Peneroplidae, Borelis and Nummulitidae in the Gulf of Elat, Red Sea. Utrecht Micropaleontological Bulletins, 15: 35-109.

Hottinger, L. 1983. Process determining the distribution of larger foraminifera in space and time. Utrecht Micropaleontological Bulletins, 30: $239-253$.

Hottinger, L. 1989. Conditions for generating carbonate platforms. Memorie della Societá Geologica Italiana, 40: 265-271.

Johnson, J.H. 1961. Limestone-building Algae and Algal Limestones. Colorado School of Mines. Golden.

Keller, G., MacLeod, N. \& Barrera, E. 1992. Eocene-Oligocene faunal turnover in planktonic foraminifera and Antarctic glaciation. In Prothero, D. R. \& Berggren, W. A. (Eds), Eocene-Oligocene Climatic and Biotic Evolution. Princeton University Press, Princeton: 218-244.

Kitazato, H. 1994. Foraminiferal microhabitats in four marine environments around Japan. Marine Micropaleontology, 24: 2941.

Kleinsmeide, W. F. J. \& Van den Berg, N. J. 1968. Surface geology of the Jabal al Akhdar, Northern Cyrenaica, Libya. In Barr, F.T. (Ed.), Geology and Archaeology of Northern Cyrenaica, Libya. The Petroleum Exploration Society of Libya, Tripoli: 115-123.

Klen, L. 1974. Geological Map of Libya, I:250000. Sheet Benghazi (NI 34-14). Explanatory Booklet. Industrial Research Center, Tripoli.

Langer, M., Hottinger, L. \& Huber, B. 1989. Functional morphology in low-diverse benthic foraminiferal assemblages from tidal flats of the North Sea. Senckenbergiana Maritima, 20: 81-99.

Lee, J. J. 1980. Nutrition and physiology of the foraminifera. In Levandowsky, M. \& Hunter, S. (Eds), Biochemistry and Physiology of Protozoa. Vol 3. Academic Press, London: 43-46.

Leutenegger, S. 1983. Specific host symbiont relationship in larger foraminifera. Micropaleontology, 29: 111-125.

Leutenegger, S. 1984. Symbiosis in benthic foraminifera: specificity and host adaptations. Journal of Foraminiferal Research, 14: 16-35.

Luterbacher, H. P. 1984. Palaeoecology of foraminifera in the Palaeogene of the southern Pyrenees. In Oertli, H. (Ed.), Benthos '83, Proceedings of the Second International Symposium on Benthic Foraminifera. Elf-Aquitaine, Pau: 389-392.

Marchetti, M. 1934. Itinerari geologici in Cirenaica. Atti Secondo Congresso Studi Coloniali, 3: 273-286.

Megerisi, M., \& Mamgain, V. D. 1980. The Upper Cretaceous-Tertiary formations of Northern Libya. In Salem, M.J. \& Busrewil, M.T. (Eds), The Geology of Libya. Vol. I. Academic Press, London: 67-72.

Morkhoven, F. P. C. M. van, Berggren, W. A. \& Edwards, A. S. 1986. Cenozoic cosmopolitan deep-water benthic foraminifera. Bulletin des Centres des Recherches Exploration et Production, Elf-Aquitaine, Memoir, 11.

Murray, J. W. 1973. Distribution and Ecology of Living Benthic Foraminiferids. Heinemann Educational, London.

Murray, J. W. 1991. Ecology and Palaeoecology of Benthic Foraminifera. Longman Scientific \& Technical, Harlow.

Olsson, R. K. \& Wise, S. W. Jr 1987. Upper Paleocene to Middle Eocene Depositional Sequences and Hiatyses in the New Jersey Atlantic Margin. Cushman Foundation for Foraminiferal Research, Special Publication, 241

Perrin, C., Bosence, D. W. J. \& Rosen, B. 1995. Quantitive approaches to palaeozonation and palaeobathymetry of corals and coralline algae in Cenozoic reefs. In Bosence, D. W. J. \& Allison P. A. (Eds), Marine Palaeoenvironmental Analysis from Fossils. Geological Society, London, Special Publication, 83: 181-229.

Pietersz, C. R. 1968. Proposed nomenclature for rock units in Northern Cyrenaica. In Barr, F. T. (Ed.), Geology and Archaeology of Northern Cyrenaica, Libya. The Petroleum Exploration Society of Libya, Tripoli: $125-130$.
Racey, A. 1994. Biostratigraphy and palaeobiogeographic significance of Tertiary nummulitids (foraminifera) from Northern Oman. In Simmons, M. D. (Ed.), Micropalaeontology and Hydrocarbon Exploration in the Middle East. Chapman \& Hall, London: 343-370.

Racey, A. 1995. Lithostratigraphy and larger foraminiferal (nummulitid) biostratigraphy of the Tertiary of northern Oman. Micropaleontology, Supplement, 41: 1-123.

Reid, P.R. \& Macintyre, I.G. 1988. Foraminiferal-algal nodules from the eastern Caribbean: growth history and implications on the value of nodules as paleoenvironmental indicators. Palaios, 3: 424-435.

Reijers, T. J. A. \& Hsü, K. J. 1986. Manual of Carbonate Sedimentology: a Lexicographical Approach. Academic Press, London.

Reiss, Z. \& Hottinger, L. 1984. The Gulf of Aqaba: Ecological Micropaleontology. Springer, Berlin.

Röhlich, P. 1974. Geological map of Libya, 1:250000. Sheet Al Bayda (NI 34-15). Explanatory Booklet. Industrial Research Center, Tripoli.

Röhlich, P. 1978. Geological development of Jabal al Akhdar, Libya. Geologische Rundschau, 67: 401-412

Röhlich, P. 1980. Tectonic development of Al Jabal al Akhdar. In Salem, M.J. \& Buserwil, M. T. (Eds), The Geology of Libya, Vol. III. Academic Press, London: 923-931.

Schaub, H. 1981. Nummulites et assilines de la Tethys Paleogene: taxanomie, phylogenie et biostratigraphie. Mémoires Suisses de Paléontologie, 104-106: 1-236 + atlas.

Schaub, H. 1983. Paleogene Tethys, domain of Nummulites. Bollettino della Societá Paleontologica Italiana, 22: 93-102.

Seiglie, G. A. 1987. Sea Level Changes and Cenozoic Larger Foraminifera with Inner Structures. Contribution from the Cushman Foundation for Foraminiferal Research, Special Publication 24: 169-186.

Serra-Kiel, J. \& Reguant, S. 1984. Paleoecological conditions and morphological variation in monospecific banks of nummulites: an example. In Oertli, H. (Ed.), Benthos '83, Proceedings of the Second International Symposium on Benthic Foraminifera. Elf-Aquitaine, Pau: 389-392.

Setiawan, J. R. 1983. Foraminifera and microfacies of the type Priabonian. Utrecht Micropaleontological Bulletins, 29: 1-173.

Sherif, K. A. T. 1991. Biostratigraphy of the Miocene in Al Khums area, northwestern Libya. In Salem, M. J., Hammuda, O. S. \& Eliagoubi, B. A. (Eds), The Geology of Libya. Vol. IV. Elsevier, Amsterdam: 14211455.

Stefanini, G. 1923. Fossili terziari della Cirenaica. Paleontographia Italica, 27: 101-146.

Stefanini, G. 1935. Breve guida alle escursioni geologiche in Cirenaica. Bollettino della Societá Geologica Italiana, 54: 1-117.

Sztràkos, K. 1979. La stratigraphie, paléoécologie, paléogéographie et les foraminifères de l'Oligocène du Nord-Est de la Hongrie. Cahiers de Micropaléontologie, 3: 1-95.

Sztràkos, K. 1982. Les foraminifères de la Marne de Buda et la limite Eocène-Oligocène en Hongrie. Cahiers de Micropaléontologie, 4: 3-49.

Travé, A., Serra-Kiel, J. \& Zamarreno I. 1996. Paleoecological interpretation of transitional environments in Eocene carbonates (NE Spain). Palaios, 11: 141-160.

Vail, P. R., Mitchum, R. M. Jr \& Thompson, S. 1977. Seismic stratigraphy and global changes of sea level. Part 4. Global cycles of relative changes of sea level. In Payton, C.E. (Ed.), Seismic Stratigraphy Application to Hydrocarbon Exploration. American Association of Petroleum Geologists Bulletin, 26: 83-97.

Wilson, J. L. 1974. Characteristics of carbonate platform margins. American Association of Petroleum Geologists Bulletin, 58: 810-824.

Wilson, J. L. 1975. Carbonate Facies in Geologic History. SpringerVerlag, Berlin.

Wray, J. L. 1977. Calcareous Algae. Developments in Paleontology and Stratigraphy, Elsevier, Amsterdam.

Zert, B. 1974. Geological Map of Libya, 1:250000. Sheet Dernah (NI3416). Explanatory Booklet. Industrial Research Center, Tripoli. 